\title{
Parameters of radish phytomass (Raphanus sativus L.) determined by vermicompost and earthworms (Eisenia fetida)
}

\author{
Peter Kováčik', Katarína Olšovská2,*, Sylwester Smoleñ ${ }^{3}$, \\ Iwona Ledwożyw-Smoleñ ${ }^{3}$
}

\begin{abstract}
${ }^{1}$ Department of Agrochemistry and Plant Nutrition, Faculty of Agrobiology and Food Resources, Slovak University of Agriculture in Nitra, Nitra 949 76, Slovakia ${ }^{2}$ Department of Plant Physiology, Faculty of Agrobiology and Food Resources, Slovak University of Agriculture in Nitra, Nitra 949 01, Slovakia ${ }^{3}$ Department of Plant Biology and Biotechnology, Faculty of Biotechnology and Horticulture, University of Agriculture in Krakow, 31-425 Krakow, Poland
\end{abstract}

\begin{abstract}
In 2-year outdoor pots experiment, which was realised in the vegetation cage situated in the campus of Slovak University of Agriculture in Nitra, both the impact of different doses of vermicompost (Vc) $(0 \%, 10 \%, 20 \%, 25 \%$ and $50 \%)$ and the number of earthworms (EW) $(0,10$ and 20 individuals/pot) in the soil substrate were studied on the quantitative and qualitative parameters of radish yield. The achieved results show that along with the increasing quantity of $\mathrm{Vc}$, the total chlorophyll content also increased proportionally. The content of vitamin $\mathrm{C}$ declined and the content of nitrates increased in both the aboveground and underground biomass. The weight of the roots and leaves of radish increased until the content of $\mathrm{Vc}$ in the substrate did not exceed $20 \%$. Vermicompost abundance $>20 \%$ led to the decline of root and leaf biomass formation. The root yield and leaf biomass were higher in the presence of $50 \%$ Vc content in the substrate, compared with the control. The EW had mostly a negative impact on radish phytomass formation, particularly both weight and root diameter. The highest percentage of roots weight decline cultivated in the treatment with EW were obtained with the least dose of $\mathrm{Vc}(10 \%)$, thereby the least quantity of fodder for the EW. The impact of EW on the total chlorophyll, vitamin C and nitrates contents in roots and leaves was non-significant. The number of EW did not influence the root diameter and content of vitamin $\mathrm{C}$; however, it affected the root weight.
\end{abstract}

Keywords: earthworms, nitrates, root weight, total chlorophyll content, vermicompost, vitamin C

\section{INTRODUCTION}

The worldwide deterioration of the environment activates both professionals and the lay public to protect nature. Nowadays, different ecological movements are working at different knowledge levels. Representatives of these movements with a lower level of professionalism in soil chemistry and soil life sciences have caused nutrition of agricultural crops to be done through organic fertilisers; this has been perceived uncritically positively by numerous groups of people. While it is a well-known fact that not only application of commercial fertilisers but also organic fertilisers could negatively affect the quality of groundwater and increase the quantity of greenhouse gases in the atmosphere (Akiyama and 
Tsuruta, 2003; Deng et al., 2017). In countries with low doses of commercial fertilisers applied in the conventional agriculture, the use of organic fertilisers negatively influences the environment more often than the application of commercial ones. To avoid the possible negative impacts of organic fertilisers on the environment, the European Commission (1991, 1999) limits the maximum annual incorporation of organic fertilisers to an amount equivalent to $170 \mathrm{~kg} \mathrm{~N} \cdot \mathrm{ha}^{-1}$ (Manojlovič et al., 2017).

The European (unscientific) population has accepted the view that fertilisation by organic fertilisers compared with mineral fertilisers results always in a higher quality of cultivated crops. However, the effect of application is given by the parameters of organic fertilisers and the rationality of their utilisation. Therefore, it is evident that the impact of organic fertilisers on the yield quantity and quality of cultivated crops could be positive and neutral, but also negative (León et al., 2012; Kmet'ová et al., 2013; Zayed et al., 2013; Chakraborty et al., 2016; Gholami et al., 2018a, 2018b; Najjari and Ghasemi, 2018). Similarly, their effect on the soil parameters and the environment is determined by the quality, dose and date of their application and could be positive or negative (Kong et al., 2014; Wu et al., 2019).

Nowadays, in many countries worldwide, the usage of commercial fertilisers is highly professional. It is based on complying with the information about several soil parameters (nutrients content, $\mathrm{pH}$, bulk density, etc.), with changes in plant requirements for nutrients during their growth (Vaněk et al., 2013). As a result, crop growers, who take into consideration the latest trends in plant nutrition, apply commercial fertilisers in doses and periods, which allow an assumption of their maximal use for yield formation.

In the practical use of organic fertilisers, the same effort has been enforced related to their economic, and, consequently ecological impact, as in the commercial fertilisers use. The fact that a great part of nutrients from organic fertilisers are fixed in organic compounds requires their application for a longer time before the period of increased nutrient uptake by plants starts, in comparison to commercial fertilisers. This time is necessary for a release of nutrients from organic bonds and mineralisation of organic compounds (Schulten and Schnitzer, 1998) as well. As so far, agronomists cannot model weather development, the time required for mineralisation of nutrients generates the opportunity for nutrient losses caused by their depletion, evaporation and erosion. This is one of the reasons why organic fertilisers (manure, liquid manure and composts) used in Slovakia contribute more to the total washed-away nitrogen in comparison with commercial fertilisers (Bielek and Kudejarov, 1991).

With the increasing percentage of nutrient use from fertilisers (industrial and organic) for yield formation of cultivated crops, the risk of their leakage into ground or surface water, as well as the risk of environmental pollution decreases. Therefore, it could be stated that, if plant nutrition is realised rationally, i.e. economically effectively, it could also be ecological.

Another myth, which has been assumed by the not non-significant part of the European population, says that the more earthworms (EW) are in the soil, the higher yield and quality of cultivated crops are achieved. However, EWs influence both the quantity and quality of cultivated crops not only positively, but also in a negative manner. The positive impact of the EW alone (different genera) and the EW in a vermicompost ( Vc) was recorded on the aboveground biomass formation of cultivated crops by Brown et al. (2004), Van Groenigen et al. (2014) and Nweke (2017). The ambiguous, positive and negative effects of EW (Pontoscolex corethrurus) on the total phytomass and tradable cabbage phytomass was presented by Nurhidayati et al. (2016). Similarly, the positive and negative influences of EW (Eisenia fetida) on the underground plant phytomass were published by Kováčik et al. (2018a). In their experiments, the EW had a negative impact on the weight of radish roots and a positive effect on the weight of carrot roots. The recorded opposite effect of the EW on radish roots in comparison with carrot roots was explained by the different effect of the EW on crops of shorter (radish) and longer (carrot) growing season. A shorter growing season did not allow the plants to regenerate sufficiently after the attack of the EW on root hairs. Statistically non-significant, positive and negative reactions of plants to the presence of EW were presented by Doan et al. (2013) and Elmer (2016). Based on meta-analyses, Van Groenigen et al. (2014) claimed that in different ecosystems the EW increase crop yields on average by $25 \%$, formation of aboveground phytomass by $23 \%$ and underground phytomass by $20 \%$.

Different attention has been paid in different countries to the research focused on the impact of individual EW number on the height and quality of yields of specific plant species. In conditions of Central Europe, but also worldwide, it is still not known how many pieces of EW of a particularly species are beneficial for cultivation of specific plants, and how many are harmful. The utility and harmfulness of EW should be evaluated not only from the aspect of yield quantity, but also from the yield quality and impact on the environment. The well-known fact is that EW activity increases the mobility of a majority of nutrients in the soil. As a positive phenomenon, improved bio-availability of nitrogen (Tripathi and Bhardwaj, 2004), phosphorus and potassium (Garg et al., 2006) leads to the increased yield and content of nutrients in cultivated crops, respectively. Nevertheless, EW also increases the mobility of metals in the soil, resulting in their increased uptake by plants and consequently, increased concentration in plants (Sizmur et al., 2011; Du et al., 2014). This is, of course, an undesirable phenomenon. An increase of heavy metal contents in plants as affected by the EW activity in soils could be many-fold (Ruiz et al., 2011). It is evident that the measure of utility and harmfulness of the increased bioavailability of nutrients in soils as a result of the EW 
activity depends significantly on the soil parameters. EW generally help to form soil aggregates (Wright and Upadhyay, 1998), which improve the water retention in nature and improve several physical, chemical and biological soil parameters (Sharma et al., 2005; Russell et al., 2016). The aim of this paper was to answer the question on how different doses of Vc (I) and the E. fetida (II) EW added to soil substrate affect both the quantity and quality of radish yield.

\section{MATERIALS AND METHODS}

\section{Experimental design and field management}

The 2-year pots experiment (2017 and 2018) was conducted in the vegetation cage (a fenced space on full sun with $10 \times 15 \mathrm{~m}$ size. On cage sides and ceiling there was a metal mesh of size $15 \mathrm{~mm} \times 15 \mathrm{~mm}$, which protected the experiment against birds of the Slovak University of Agriculture in Nitra, situated in the university campus $\left(48^{\circ} 18^{\prime} \mathrm{N}, 18^{\circ} 05^{\prime} \mathrm{E}\right)$ to study the impact of two factors (I - quantity of Vc, and II - number of EW) on formation of radish phytomass. The total number of treatments was 13. Treatment 1 was a control treatment (soil without Vc); Treatments 2-5 were targeted to determine the effect of $10 \%, 20 \%, 25 \%$ and $50 \%$ proportion of $\mathrm{Vc}$ on the total weight of soil substrate; Treatments 6-13 were established to detect the influence of 10 and $20 \mathrm{EW}$ in the growing medium, as tested in Treatments 2-5.

In the experiment, five different growing substrates were mixed to fill the pots, while each pot was cylindrically shaped with $35 \mathrm{~cm}$ height and $35 \mathrm{~cm}$ diameter holding $20 \mathrm{~kg}$ of the substrate. In Treatment 1 , the substrate was composed only from the soil, while the substrate in Treatments 2-5 was represented by four types of mixtures consisting of $18,16,15$ and $10 \mathrm{~kg}$ of soil and 2, 4, 5 and $10 \mathrm{~kg}$ of $\mathrm{Vc}$, respectively. The basic chemical parameters of both used soil (S) and Vc are indicated in Table 1.

The soil-to-Vc phytomass weight ratio in the created mixtures was as follows: 9:1, 4:1, 3:1 and 1:1. In Treatments 6-13, the same growing media were used like in Treatments 2-5, whereby EW (E. fetida, red worms) were added to the growing substrate. The EW used in the experiment was supplied by VermiVital Ltd. The following pairs of treatments, such as 6 and 7, 8 and 9, 10 and 11, 12 and 13 contained the identical substrate like Treatments $2-5$. Ten red worms were added in the treatments with even numbers $(8,10,12)$, and 20 red worms in the treatments with odd numbers $(9,11,13)$ (Tables 2-8).
In the experiment, the Haplic Luvisol from the 0.0-0.25 m layer and standard Vc (VermiVital, Ltd. Company) were used. Before filling pots with growing media, the plastic net was placed at the bottom of all pots, which prevented potential escape of EW. Pots with weighted substrate were put on dishmats, deep enough to be able to hold $1,000 \mathrm{~mL}$ of the leaked soil solution resulting from intensive precipitations. The leaked solution returned back to the pots.

The experiment was conducted according to the random arrangement method of pots with each treatment in four repetitions (one repetition $=1$ pot). The model crop was radish (Raphanus sativus L.) cv. 'Granát' by the company Osiva Moravia, which is cultivated for root consumption. In both years, the sowing of sufficient number of seeds into the pots took place on 16 March. Subsequently, the experiment was irrigated to the level of $75 \%$ field water capacity (FWC). After the emergence of plant seedlings, they were unitised by thinning down their number to ensure the same number of seedlings per pot (50 plants per one repetition), that is, enough biomass for three samplings. In the following 3 weeks, all pots were irrigated by the same dose of water containing the minimal quantity of nutrients. During the last 14 days of the experiment, Treatments $2-13$ were irrigated by higher doses of water, because plants evaporated more water because of a significantly larger leaf area. In the course of the growing season (24 April, and 3 and 9 May, i.e. in 27/39, 36/48 and 42/54 days after emergence of plants/ sowing) a total of three samples of plant material were collected (plants of radish emerged after 12 days from the sowing). Ten average individuals were taken from each treatment and repetition, which served for the evaluation of root and leaf weights. The contents of nitrates and vitamin $\mathrm{C}$ were determined in the roots and leaves during the second and third samplings. The total chlorophyll content was determined in the leaves. The diameter of root thickness was measured by slide calliper. For the purpose of sales, the radish crop is usually harvested twice or even more times during the vegetation season, meaning the yield harvests follow shortly one after another. Therefore, the sampling of plant material was pursued twice, in only 6-day intervals (3 and 9 May).

\section{Analyses of soil and $V c$}

The following analytical methods were used in the experiment to quantify the agrochemical parameters of the soil and Vc: $\mathrm{N}-\mathrm{NH}_{4}^{+}$by Nessler's colorimetric method; $\mathrm{N}-\mathrm{NO}_{3}{ }^{-}$by colorimetric method with phenol2.4-disulphonic acid, where the extract from the soil was achieved by using water solution of $1 \% \mathrm{~K}_{2} \mathrm{SO}_{4}$

Table 1. Parameters of soil and Vc used in the experiment.

\begin{tabular}{|c|c|c|c|c|c|c|c|c|c|c|c|}
\hline \multirow[t]{2}{*}{ Subs. } & $\mathrm{N}_{\text {in }}$ & $\mathrm{P}$ & K & $\mathrm{Ca}$ & $\mathrm{Mg}$ & $\mathrm{S}$ & $\mathrm{N}_{\text {tot }}$ & $\mathrm{C}_{\mathrm{ox}}$ & \multirow[t]{2}{*}{$\mathrm{C}: \mathrm{N}$} & EC & \multirow[t]{2}{*}{$\mathrm{pH}_{\mathrm{KCl}}$} \\
\hline & \multicolumn{6}{|c|}{$\left(\mathrm{mg} \cdot \mathrm{kg}^{-1}\right)$} & \multicolumn{2}{|c|}{$(\%)$} & & $\left(\mathrm{mS} \cdot \mathrm{cm}^{-1}\right.$ & \\
\hline $\mathrm{S}$ & 9.2 & 17.8 & 173 & 3,100 & 452 & 4.4 & 0.07 & 0.90 & 11.88 & 0.12 & 6.35 \\
\hline $\mathrm{Vc}$ & 310.1 & 3,085 & 8,763 & 5,135 & 3,252 & 2,068 & 2.97 & 19.89 & 5.53 & 4.98 & 7.33 \\
\hline
\end{tabular}

Subs., substrate; S, soil; Vc, vermicompost. 
(Kováčik, 1997). Inorganic $\mathrm{N}\left(\mathrm{N}_{\mathrm{in}}\right)$ was calculated as a sum of $\mathrm{N}-\mathrm{NH}_{4}^{+}$and $\mathrm{N}-\mathrm{NO}_{3}^{-}\left(\mathrm{N}_{\text {in }}=\mathrm{NNH}_{4}^{+}+\mathrm{N}-\mathrm{NO}_{3}^{-}\right)$. The available $\mathrm{P}, \mathrm{K}, \mathrm{Ca}$ and $\mathrm{Mg}$ contents were determined by Mehlich 3 extraction procedure (Mehlich, 1984). The content of $\mathrm{P}$ was determined by colorimetric method, $\mathrm{K}$ by flame photometry, $\mathrm{Ca}$ and $\mathrm{Mg}$ by atomic absorption spectrophotometry, S was detected spectrophotometrically (in the leachate of ammonium acetate), $\mathrm{N}_{t}$ by distillation after mineralisation of strong $\mathrm{H}_{2} \mathrm{SO}_{4}$ (Bremner, 1960), $\mathrm{C}_{\text {ox }}$ spectrophotometrically after the oxidation according to Tyurin (Dziadowiec and Gonet, 1999), EC by specific electrical conductivity method and $\mathrm{pH} / \mathrm{KCl}$ (in solution of $1.0 \mathrm{~mol} \cdot \mathrm{dm}^{-3} \mathrm{KCl}$ ) potentiometrically.

\section{Determination of total chlorophylls and nitrates}

The chlorophyll content in fully developed leaves was analysed from the $80 \%$ acetone extract spectrophotometricaly according to the method of Šesták and Čatský (1966) and the absorbance of the extract was converted into the concentration unit $\left(\mathrm{mg} \cdot \mathrm{m}^{-2}\right)$ after the equations of Lichtenthaler (1987).

Determination of nitrates content was conducted as the extracting method from fresh plant samples and measured by use of ion-selective electrode (type 07-35) and reference electrode (type RCE 101) as the electro-motoric power according to Hubáček and Bernatzik (1976).

\section{Determination of $L$-ascorbic acid}

L-ascorbic acid was determined by HPLC Agilent 1260 with quaternary solvent manager coupled with degasser, sample manager, column manager and DAD detector. All analyses were performed on C18 end capped column. Mobile phases consisted of methanol (B) and $0.1 \% \mathrm{H}_{3} \mathrm{PO}_{4}(\mathrm{C})$. The detection wavelength was set at $256 \mathrm{~nm}$. The spectral data were collected and processed using the Agilent OpenLab ChemStation software for LC 3D Systems (Stan et al., 2014).

\section{Statistical analysis}

The obtained results were processed mathematically and statistically by multifactorial analysis of variance (ANOVA) and by the Pearson's correlation coefficient ( $r$ ). The differences between the treatments were evaluated by LSD test at the significance level of $\alpha=0.05$. The Pearson's correlation coefficient $(r)$ was processed by simple regression analysis at the significance levels of $\alpha=0.05$ and $\alpha=0.01$. The PC statistical program Statgraphics (version 5.0) was used.

\section{RESULTS AND DISCUSSION}

\section{Weight of aboveground and underground phytomass}

\section{Effect of time}

With progressive days of the experiment, the weight of radish phytomass was being increased (Tables 2 and 3). On average, root weight increased 46.43 times (by $108.12 \mathrm{~g}$ per 10 individuals) between the first and second samplings, i.e. between the $27^{\text {th }}$ and $36^{\text {th }}$ days

Table 2. Impact of $\mathrm{Vc}$ and $\mathrm{EW}$ on the dynamics of radish roots and leaves weight changes.

\begin{tabular}{|c|c|c|c|c|c|c|c|}
\hline \multicolumn{2}{|c|}{ Treatment } & \multicolumn{2}{|c|}{$\begin{array}{l}\text { 24. IV. (27 days after } \\
\text { emergence of plants }\end{array}$} & \multirow{2}{*}{\multicolumn{2}{|c|}{$\begin{array}{l}\text { 3. V. (36 days after emergence } \\
\text { of plants } \\
\text { g per } 10 \text { individuals } \\
\end{array}$}} & \multicolumn{2}{|c|}{$\begin{array}{l}\text { 9. V. (42 days after emergence } \\
\text { of plants } \\
\end{array}$} \\
\hline \multirow[t]{2}{*}{ No. } & \multirow[t]{2}{*}{ Mark } & & & & & & \\
\hline & & Roots & Leaves & Root & Leaves & Root & Leaves \\
\hline 1 & $\mathrm{~S}$ & $2.04 \mathrm{bc}$ & $14.75 \mathrm{a}$ & $20.92 \mathrm{a}$ & $16.00 \mathrm{a}$ & $29.94 \mathrm{a}$ & $18.63 \mathrm{a}$ \\
\hline 2 & $\mathrm{SVc}_{9: 1}$ & $2.94 \mathrm{~h}$ & $21.08 \mathrm{de}$ & $149.60 \mathrm{f}$ & $83.91 \mathrm{def}$ & $186.92 \mathrm{e}$ & $104.60 \mathrm{~cd}$ \\
\hline 3 & $\mathrm{SVc}_{4: 1}$ & $3.66 \mathrm{i}$ & $22.56 \mathrm{e}$ & $154.72 \mathrm{~g}$ & $95.96 \mathrm{~g}$ & $220,27 \mathrm{f}$ & $147.78 \mathrm{f}$ \\
\hline 4 & $\mathrm{SVc}_{3: 1}$ & $2.81 \mathrm{~h}$ & 20.25 cde & $146.70 \mathrm{f}$ & $85.99 \mathrm{fg}$ & $215.42 \mathrm{f}$ & $136.35 \mathrm{f}$ \\
\hline 5 & $\mathrm{SVc}_{1: 1}$ & $2.19 \mathrm{~cd}$ & $17.32 \mathrm{abc}$ & $101.98 \mathrm{c}$ & 84.87 efg & $141.51 \mathrm{c}$ & $113.23 \mathrm{de}$ \\
\hline 6 & $\mathrm{SVc}_{9: 1}+\mathrm{EW}_{10}$ & $1.99 \mathrm{~b}$ & $15.47 \mathrm{ab}$ & $107.00 \mathrm{~d}$ & $59.18 \mathrm{~b}$ & $143.00 \mathrm{c}$ & $70.78 \mathrm{~b}$ \\
\hline 7 & $\mathrm{SVc}_{9: 1}+\mathrm{EW}_{20}$ & $1.65 \mathrm{a}$ & $14.47 \mathrm{a}$ & $96.04 \mathrm{~b}$ & $56.38 \mathrm{~b}$ & $128.98 \mathrm{~b}$ & $66.76 \mathrm{~b}$ \\
\hline 8 & $\mathrm{SVc}_{4: 1}+\mathrm{EW}_{10}$ & $2.55 \mathrm{~g}$ & $19.06 \mathrm{~cd}$ & $117.12 \mathrm{e}$ & $75.58 \mathrm{cdef}$ & $183.60 \mathrm{e}$ & $95.74 \mathrm{c}$ \\
\hline 9 & $\mathrm{SVc}_{4: 1}+\mathrm{EW}_{20}$ & $2.25 \mathrm{df}$ & $17.21 \mathrm{abc}$ & $115.88 \mathrm{e}$ & 74.21 cde & $181.44 \mathrm{e}$ & $91.58 \mathrm{c}$ \\
\hline 10 & $\mathrm{SVc}_{3: 1}+\mathrm{EW}_{10}$ & $2.54 \mathrm{~g}$ & $18.25 \mathrm{bcd}$ & $109.02 \mathrm{~d}$ & $72.99 \mathrm{~cd}$ & $167.33 \mathrm{~d}$ & $120.14 \mathrm{e}$ \\
\hline 11 & $\mathrm{SVc}_{3: 1}+\mathrm{EW}_{20}$ & $2.44 \mathrm{fg}$ & $17.96 \mathrm{abc}$ & $107.16 \mathrm{~d}$ & $72.99 \mathrm{~cd}$ & $163.26 \mathrm{~d}$ & $118.60 \mathrm{e}$ \\
\hline 12 & $\mathrm{SVc}_{1: 1}+\mathrm{EW}_{10}$ & $1.96 \mathrm{~b}$ & $17.38 \mathrm{abc}$ & $105.20 \mathrm{~cd}$ & $70.77 \mathrm{c}$ & $141.77 \mathrm{c}$ & $115.76 \mathrm{de}$ \\
\hline 13 & $\mathrm{SVc}_{1: 1}+\mathrm{EW}_{20}$ & $1.98 \mathrm{~b}$ & $17.34 \mathrm{abc}$ & $105.20 \mathrm{~cd}$ & $71.02 \mathrm{c}$ & $139.64 \mathrm{c}$ & $114.80 \mathrm{de}$ \\
\hline $1-13$ & & 2.38 & 17.93 & 110.50 & 70.76 & 157.16 & 101.13 \\
\hline $2-5$ & & 2.90 & 20.30 & 138.25 & 87.68 & 191.03 & 125.49 \\
\hline $6-13$ & & 2.17 & 17.14 & 107.83 & 69.14 & 156.13 & 99.27 \\
\hline $6,8,10,12$ & & 2.26 & 17.54 & 109.59 & 69.63 & 158.93 & 100.61 \\
\hline $7,9,11,13$ & & 2.08 & 16.75 & 106.07 & 68.65 & 153.33 & 97.94 \\
\hline LSD $_{0.05}$ & & 0.195 & 3.477 & 4.734 & 11.429 & 9.371 & 13.378 \\
\hline
\end{tabular}

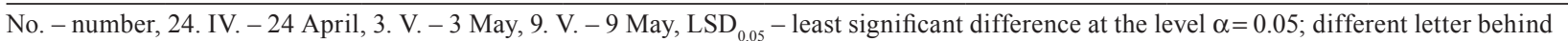
a numerical value respond to the statistically significant difference at the level $95.0 \%$

EW, earthworms; Vc, vermicompost. 
from plant germination (totally 9 days). The weight of leaves was increased by only 3.95 times (by 52.83 g per 10 individuals). Between the second and third samplings (totally 6 days) the root weight accumulated only 1.42 times (by $46.66 \mathrm{~g}$ per 10 individuals) and the weight of leaves 1.43 times (30.37 g per 10 individuals), meaning that the growth dynamics of both the aboveground and underground phytomass were almost equal. This fact indicates that radish roots increased their weight most intensively after 27 days from plant emergence, i.e. in the second half of the radish growing season. Roots and leaves grew and increased their weight up to the $42^{\text {nd }}$ day of the growing season, i.e. until the end of the experiment, when the highest weights of leaves and roots were recorded. From the $36^{\text {th }}$ day of the growing season the growth dynamics slowed down, while the leaves and roots growth had almost the equal dynamics, in spite of the fact that the absolute value of weight gain of roots was higher than the absolute value of weight gain of leaves.

During the first days of the radish growing season the ratio of leaves to roots weight (L:R) was higher than 6:1 in each treatment (Table 3). It is evident that at the beginning of the growing season the aboveground phytomass was formed faster compared with underground phytomass. After 27 days of the growing season the root growth was more intensive as a result of the transfer of photosynthates from leaves to roots and, consequently, leaf growth decline. On the $36^{\text {th }}$ day of the growing season the leaf weight was lower than the root weight. A faster root growth compared to leaves caused that in the stage of technological ripeness (3 and 9 May) the ratio of roots-to-total phytomass was higher than $50 \%$ and achieved the values of $60.96 \%$ and $60.85 \%$ (Tables 2 and 3). Similarly, the roots of sugar beet, fodder beet and turnip can grow more intensively than the leaves. The change in the ratio of roots-to-leaves growth rate occurs predominantly during the changing sunlight intensity and nutrition intensity (Suqiura and Tateno, 2011). Formation of leaves is supported heavily by nutrition, however, the light sufficiency has the opposite effect (Poorter et al., 2012). The change of leaves-to-roots weight ratio occurs probably only to a certain extent, and it is determined genetically, via optimisation of the growth rate of the whole plants (Osone and Tateno, 2003). Nowadays, attention is focused on the possibility to predict the yield quantity, based on the determination of the dependence between the roots-to-leaves weight ratio and yield.

\section{Effect of $V c$}

According to Table 2, the addition of $\mathrm{Vc}$ into the soil (Treatments 2-5) resulted in both the fast radish growth and the increase in the roots-to-leaves weight ratio. The increase of aboveground and underground phytomass weights was measurable already on the $27^{\text {th }}$ day from the beginning of plant emergence. The speed of Vc effect was high, because of high content of available nutrients, as referred in Table 1. Many countries tend to state the nutrients content in their total forms, when declaring the parameters of organic fertilisers; however, these are not sufficient indicators of their quality. Therefore,

Table 3. Impact of $\mathrm{Vc}$ and $\mathrm{EW}$ on the dynamics of radish leaves to roots phytomass ratio and total phytomass content changes.

\begin{tabular}{|c|c|c|c|c|c|c|c|}
\hline \multicolumn{2}{|c|}{ Treatment } & \multicolumn{2}{|c|}{$\begin{array}{l}\text { 24. IV. (27 days after } \\
\text { emergence of plants }\end{array}$} & \multicolumn{2}{|c|}{$\begin{array}{l}\text { 3. V. (36 days after } \\
\text { emergence of plants }\end{array}$} & \multicolumn{2}{|c|}{$\begin{array}{l}\text { 9. V. (42 days after emergence } \\
\text { of plants }\end{array}$} \\
\hline No. & Mark & $\mathrm{L}: \mathrm{R}$ & $\mathrm{L}+\mathrm{R}$ & $\mathrm{L}: \mathrm{R}$ & $\mathrm{L}+\mathrm{R}$ & L:R & $\mathrm{L}+\mathrm{R}$ \\
\hline 1 & $\mathrm{~S}$ & 7.23 & 16.79 & 0.76 & 36.92 & 0.62 & 48.57 \\
\hline 2 & $\mathrm{SVc}_{9: 1}$ & 7.17 & 24.02 & 0.56 & 233.51 & 0.56 & 291.52 \\
\hline 3 & $\mathrm{SVc}_{4: 1}$ & 6.16 & 26.22 & 0.62 & 250.68 & 0.67 & 368.05 \\
\hline 4 & $\mathrm{SVc}_{3: 1}$ & 7.21 & 23.06 & 0.59 & 232.69 & 0.63 & 351.77 \\
\hline 5 & $\mathrm{SVc}_{1: 1}$ & 7.91 & 19.51 & 0.83 & 186.85 & 0.80 & 254.74 \\
\hline 6 & $\mathrm{SVc}_{9: 1}+\mathrm{EW}_{10}$ & 7.77 & 17.46 & 0.55 & 166.18 & 0.49 & 213.78 \\
\hline 7 & $\mathrm{SVc}_{9: 1}+\mathrm{EW}_{20}$ & 8.77 & 16.12 & 0.59 & 152.42 & 0.52 & 195.74 \\
\hline 8 & $\mathrm{SVc}_{4: 1}+\mathrm{EW}_{10}$ & 7.47 & 21.61 & 0.65 & 192.70 & 0.52 & 279.34 \\
\hline 9 & $\mathrm{SVc}_{4: 1}+\mathrm{EW}_{20}$ & 7.65 & 19.46 & 0.64 & 190.09 & 0.50 & 273.02 \\
\hline 10 & $\mathrm{SVc}_{3: 1}+\mathrm{EW}_{10}$ & 7.19 & 20.79 & 0.67 & 182.01 & 0.72 & 287.47 \\
\hline 11 & $\mathrm{SVc}_{3: 1}+\mathrm{EW}_{20}$ & 7.36 & 20.40 & 0.68 & 180.15 & 0.73 & 281.86 \\
\hline 12 & $\mathrm{SVc}_{1: 1}+\mathrm{EW}_{10}$ & 8.87 & 19.34 & 0.67 & 175.97 & 0.82 & 257.53 \\
\hline 13 & $\mathrm{SVc}_{1: 1}+\mathrm{EW}_{20}$ & 8.76 & 19.32 & 0.68 & 176.22 & 0.82 & 254.44 \\
\hline $1-13$ & & 7.66 & 20.32 & 0.65 & 181.26 & 0.65 & 258.29 \\
\hline $2-5$ & & 7.11 & 23.20 & 0.65 & 225.93 & 0.67 & 316.52 \\
\hline $6-13$ & & 7.98 & 19.31 & 0.64 & 176.97 & 0.64 & 255.40 \\
\hline $6,8,10,12$ & & 7.83 & 19.80 & 0.64 & 179.22 & 0.64 & 259.53 \\
\hline $7,9,11,13$ & & 8.14 & 18.83 & 0.65 & 174.72 & 0.64 & 251.27 \\
\hline
\end{tabular}

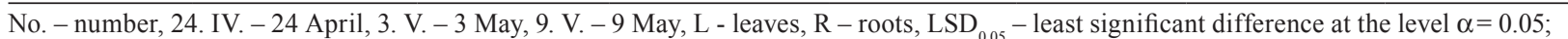
different letter behind a numerical value respond to the statistically significant difference at the level $95.0 \%$

EW, earthworms; Vc, vermicompost. 
in the process of declaration of the quality of organic fertilisers, it is advisable to declare also the content of available nutrients, which affect plant growth markedly.

On the $36^{\text {th }}$ day, the average weight of radish roots was 6.61 times higher and the average leaf weight was 5.48 times higher in the treatment with $\mathrm{Vc}(2-5)$, than in the control treatment without Vc (1). On the $42^{\text {nd }}$ day of the growing season in treatments with Vc (2-5), the average weight of radish roots was 6.38 times higher and the leaf weight was 6.74 higher, compared with the control treatment (without $\mathrm{Vc}$ ).

The significant multiple increases of phytomass weight resulting from the $\mathrm{Vc}$ addition into the soil approved the knowledge that the achievement of high yields is not possible without the application of considerable quantities of easily available nutrients (Cooke, 1982; Cong et al., 2019). At the same time, recording more dynamic growth of roots weight compared to leaves weight in treatments with $\mathrm{Vc}$ confirmed the fact that fertilisation by nitrogen usually determines a more significant growth of roots than leaves (Suqiura and Tateno, 2011).

The L:R ratio in Treatment 5 (Table 3) was higher in all the three samples of plant material compared to the control treatment, and in contrast to the same ratio in Treatments $2-4$, which means that the $50 \%$ proportion of used (high quality) Vc in the growing medium was ineffective. This must be taken into account, because the main utility part of radish during its cultivation is roots, not leaves. In Treatments $2-4$ the L:R ratios were smaller, even comparable to the control L:R ratio. It signalises that $10 \%, 20 \%$ and $25 \%$ proportion of $\mathrm{Vc}$ resulted mainly in roots formation, or at least balanced roots-to-leaves formation. In many Asian countries, radish is grown not only for root consumption, but often predominantly for leaves consumption (Bhatnagar and Azhar, 2016). Thus, it is highly probable that growers of radish leafy varieties will like the information that the highest leaves-to-roots weight ratio was recorded in the treatment with the highest proportion (50\%) of Vc.

Along with the rise of $\mathrm{Vc}$ proportion in the soil substrate (by decreasing the ratio of soil to $\mathrm{Vc}$ ) to the ratio of 1 unit Vc to 4 units $S$ (Treatments 2 and 3), the weights of radish roots and leaves were increased (Table 2). In terms of this ratio the highest weight of the radish aboveground and underground phytomass was achieved. The addition of $\mathrm{Vc}$ to $\mathrm{S}$ was above the ratio of $1: 4$, i.e. above $20 \%$ content $\mathrm{Vc}$ in the growing medium (Treatments 4 and 5) led to the gradual decreasing intensity of radish roots and leaves formation. This fact affirms that in order to achieve the highest yield of radish roots, the proportion of tested $\mathrm{Vc}$ in the soil with low contents of available N, P and K (Table 1) should not be higher than $20 \%$ (Treatment 3 ).

In the substrates with the ratio of $\mathrm{Vc}: \mathrm{S}$ at the level $1: 3$ and $1: 1$, the smaller underground and aboveground phytomass were formed than in the treatment with the ratio of Vc:S at 1:4; however, it was still significantly higher than in the treatment without Vc. This finding offers the opportunity to use Vc in soils with lower contents of available nutrients (Table 1) in relatively high doses ( $25 \%$ and $50 \%$ proportion in substrate), mainly in the case of a surplus production of $\mathrm{Vc}$ without risk of yield decreases.

In Slovakia, a local surplus production of composts is a serious problem. It is a consequence of disproportion between the increasing production of composts and the limited possibility of their application. The rising production of composts results from the legal obligation of inhabitants in Slovakia to compost biologically degradable wastes. The diminishing opportunity of their application into soils is caused, on one hand, by continuous decrease of private house gardens used for gardening, where so far the compost has been used; on the other hand, it results from the increasing disbelief in the quality of composts produced by non-agricultural companies. Therefore, the findings about the addition of $\mathrm{Vc}$ at the level of $50 \%$ of the total weight of soil substrate (in the top-soil layer) into soil with low available nutrient contents show that yield can be increased, which is a significant practical knowledge. It is necessary to take into account that application of high doses of $\mathrm{Vc}$ into soils should be carried out only in justified cases, in particular, in areas where the quality of groundwater and parameters of the environment will not be worsened.

The average root thickness of radish cultivated in the treatment without $\mathrm{Vc}$ (Treatment 1) was lower than $2.0 \mathrm{~cm}(1.46 \mathrm{~cm}$ and $1.69 \mathrm{~cm})$. For this reason, roots cultivated in the control variant are almost unmarketable (Table 4). In the treatments with applied Vc (Treatments 2-5), the average root thickness was bigger than $2.0 \mathrm{~cm}$, which satisfies the requirement of a majority of multiple stores. On the $36^{\text {th }}$ day of the growing season the root thickness varied in the interval of $2.96 \mathrm{~cm}$ to $3.36 \mathrm{~cm}$, and on the $42^{\text {nd }}$ day of the growing season it varied from $3.08 \mathrm{~cm}$ to $3.72 \mathrm{~cm}$.

The effect of Vc on root thickness corresponded with its impact on root weight. The highest root thickness was achieved in the treatment with $\mathrm{S}: \mathrm{Vc}$ ratio of $4: 1$ (Treatment 3). The decrease of $\mathrm{S}: \mathrm{Vc}$ ratio under $4: 1$, i.e. the increase of Vc proportion in the soil substrate above $20 \%$ (Treatments 4 and 5) led to the gradual decrease of radish root thickness. Analyses of Treatments 2-5 showed the smallest root thickness in Treatment 5.

This information proves that according to the normal distribution curve of the functional relationship of between the yield and $\mathrm{N}$ concentration in plants, the enhancement of $\mathrm{N}$ concentration in plants increases the yield up to a so-called breaking point, from which additional increases of $\mathrm{N}$ doses have a depressive impact on yield formation. The breaking point is determined by several factors, e.g. plant requirements for nutrients and soil nutrient reserves. In this sense, even low doses of fertilisers can result in decrease of yields in the case of their application into soils, which are supplied sufficiently by nutrients, or if the crops with very low requirements 
Table 4. Impact of Vc and EW on the changes of radish roots diameter.

\begin{tabular}{|c|c|c|c|c|c|}
\hline \multicolumn{2}{|c|}{ Treatment } & \multicolumn{2}{|c|}{ 3. V. (36 days after emergence of plants) } & \multicolumn{2}{|c|}{ 9. V. (42 days after emergence of plants) } \\
\hline No. & Mark & $\mathrm{cm}$ & $\%$ & $\mathrm{~cm}$ & $\%$ \\
\hline 1 & $\mathrm{~S}$ & $1.46 \mathrm{a}$ & 100.00 & $1.69 \mathrm{a}$ & 100.00 \\
\hline 2 & $\mathrm{SVc}_{9: 1}$ & $3.15 \mathrm{fg}$ & 215.75 & $3.31 \mathrm{ef}$ & 195.86 \\
\hline 3 & $\mathrm{SVc}_{4: 1}$ & $3.36 \mathrm{~g}$ & 230.14 & $3.72 \mathrm{~g}$ & 220.12 \\
\hline 4 & $\mathrm{SVc}_{3: 1}$ & $3.21 \mathrm{fg}$ & 219.86 & $3.64 \mathrm{fg}$ & 215.38 \\
\hline 5 & $\mathrm{SVc}_{1: 1}$ & $2.96 \mathrm{ef}$ & 202.74 & 3.08 cde & 182.25 \\
\hline 6 & $\mathrm{SVc}_{9: 1}+\mathrm{EW}_{10}$ & $2.78 \mathrm{cde}$ & 190.41 & $2.85 \mathrm{bcd}$ & 168.64 \\
\hline 7 & $\mathrm{SVc}_{9: 1}+\mathrm{EW}_{20}$ & $2.59 \mathrm{bcd}$ & 177.40 & $2.71 \mathrm{bc}$ & 160.36 \\
\hline 8 & $\mathrm{SVc}_{4: 1}+\mathrm{EW}_{10}$ & $2.97 \mathrm{ef}$ & 203.42 & $3.29 \mathrm{ef}$ & 194.67 \\
\hline 9 & $\mathrm{SVc}_{4: 1}+\mathrm{EW}_{20}$ & $2.94 \mathrm{def}$ & 201.40 & $3.22 \mathrm{de}$ & 190.53 \\
\hline 10 & $\mathrm{SVc}_{3: 1}+\mathrm{EW}_{10}$ & 2.76 bcde & 189.04 & 3.04 cde & 179.88 \\
\hline 11 & $\mathrm{SVc}_{3: 1}+\mathrm{EW}_{20}$ & $2.68 \mathrm{bcde}$ & 183.56 & $2.90 \mathrm{bcd}$ & 171.60 \\
\hline 12 & $\mathrm{SVc}_{1: 1}+\mathrm{EW}_{10}$ & $2.53 \mathrm{bc}$ & 173.29 & $2,79 \mathrm{bc}$ & 165.09 \\
\hline 13 & $\mathrm{SVc}_{1: 1}+\mathrm{EW}_{20}$ & $2.41 \mathrm{~b}$ & 16.07 & $2.66 \mathrm{~b}$ & 157.40 \\
\hline $1-13$ & & 2.75 & - & 2.99 & - \\
\hline $2-5$ & & 3.17 & - & 3.44 & - \\
\hline $6-13$ & & 2.71 & - & 2.93 & - \\
\hline $6,8,10,12$ & & 2.76 & - & 2.99 & - \\
\hline $7,9,11,13$ & & 2.66 & - & 2.87 & - \\
\hline $\mathrm{LSD}_{0.05}$ & & 0.351 & & 0.377 & \\
\hline
\end{tabular}

No. - number, 24. IV. - 24. April, 3. V. - 3 May, 9. V. - 9 May, LSD $_{0.05}$ - least significant difference at the level $\alpha=0.05$; different letter behind a numerical value respond to the statistically significant difference at the level $95.0 \%$

EW, earthworms; Vc, vermicompost.

for nutrients are cultivated, as it was recorded by Berti et al. (2009); Liao et al. (2009); Li et al. (2015); and Adekiya et al. (2019). Disproportional and excessive plant nutrition is not only uneconomic, but also non-ecological (Chaudhuri et al., 2016).

\section{Effect of the presence of $E W$}

The EW affected mostly negatively formation of radish aboveground and underground phytomass during the whole experiment (Treatments 6-13 vs Treatments 2-5).

The influence of EW on root and leaf weights was not identical during the growing season. The percentual drop of radish roots weight as a result of presented EW in soil substrates was decreased in the course of the growing season. On the contrary, the negative impact of EW on leaves weight was higher in the $2^{\text {nd }}$ and $3^{\text {rd }}$ samplings ( 3 and 9 May) in comparison to the first sampling (Table 2).

On the $27^{\text {th }}, 36^{\text {th }}$ and $42^{\text {nd }}$ days of the growing season, the roots weight treated with $\mathrm{EW}$ was lower (averages in Treatments $6-13$ ) by $25.2 \%, 22.0 \%$ and $18,3 \%$, i.e. by $0.73 \mathrm{~g}, 30.42 \mathrm{~g}$ and $34.9 \mathrm{~g}$ per 10 individuals, respectively, than the roots weight not treated with EW (averages in Treatments 2-5). Similarly, also the leaves weight in the treatments with EWs (average Treatments 6-13) was lower on the $27^{\text {th }}, 36^{\text {th }}$ and $42^{\text {nd }}$ days of the growing season by $15.57 \%, 21.1 \%$ and $20.9 \%$, i.e. by $3.16 \mathrm{~g}, 18.54 \mathrm{~g}$ and $26.2 \mathrm{~g}$ per 10 individuals, respectively, than the leaves weight cultivated in the treatments without EW (average Treatments 2-5). The submitted findings are in contradiction with the data published by Xiao et al. (2018), who, based on the meta-analyses, argue that EW in soil substrate significantly elevated plant aboveground biomass by $16 \%$, underground biomass by $29 \%$ and total biomass by $22 \%$. On the contrary, they support the opinion that roots are one of the main contributors of the principal foodsource of EW and may act well as an attractant to them (Brown et al., 2000). The idea that root hairs can be attacked by EW in the initial period of plant growing was presented by Kováčik et al. (2018b). The gradual decrease of roots weight from the $27^{\text {th }}$ to the $42^{\text {nd }}$ days of the growing season caused by EW (Table 2) corresponds with the given view.

As a result of the presented $\mathrm{EW}$, radish roots weight (overall of the second and third samplings) was decreased by $65.32 \mathrm{~g}$ per 10 individuals and leaves weight decreased by $44.74 \mathrm{~g}$ per 10 individuals. It is evident that EW had a more negative impact on the roots weight than leaves weight (Table 2). Therefore, the finding can be more significant for growers of radish root varieties.

The following comparisons, such as Treatment 2 vs Treatments 6 and 7, Treatment 3 vs Treatments 8 and 9, Treatment 4 vs Treatments 10 and 11, Treatment 5 vs Treatment 12 and 13 indicate that the percentage of roots weight decline cultivated in treatments with EW (in all three samplings) was the highest compared with treatments without EW, where the growing medium contained the least quantity of $\mathrm{Vc}(10 \%)$. The root weight decreases between Treatment 2 and Treatments $(6+7) / 2$ were at the level of $38.59 \%, 32.14 \%$ and $27.2 \%$ on the $27^{\text {th }}, 36^{\text {th }}$ and $42^{\text {nd }}$ days of the growing season, respectively. On the contrary, EW caused the least percentual fall of root weight cultivated in treatments, 
where the substrate contained the maximum, i.e. $50 \%$ of Vc (Treatment 5 vs. 12 and 13). The drop of root weight between Treatment 5 and Treatments $(12+13) / 2$ was on average $2.47 \%$ in all the three samplings. Based on these facts, it is possible to state the hypothesis that if red worms have enough appropriate fodder (compost, Vc, crop residues, etc.) in its environment, it will not attack the root hairs of young plants. The yield of cultivated crops will be higher.

EWs affected the root thickness (diameter) similar to the root weight (Treatment 2 vs Treatments 6 and 7, Treatment 3 vs Treatments 8 and 9, Treatment 4 vs Treatments 10 and 11, Treatment 5 . vs Treatments 12 and 13). They decreased the root thickness in the second as well as in the third sampling. The only exception was Treatment 12 in the third sampling, where the drop in root weight was non-significant in relation to the treatment without EW (Treatment 5) (Table 4). The average root thickness in the treatments with $\mathrm{Vc}$ and without EW (Treatments 2-5) increased in comparison with radish average root thicknesses cultivated in the treatments with Vc and EW (Treatments 6-13) on the $36^{\text {th }}$ day of radish growing season by $0.46 \mathrm{~cm}$ and on the $42^{\text {nd }}$ day by $0.51 \mathrm{~cm}$, respectively.

\section{Effect of EW number}

Not only the presence of EW in the substrate, but also their number determined the formation of radish phytomass (Treatment 6 vs Treatment 7, Treatment 8 vs. Treatment 9, Treatment 10 vs. Treatment 11, Treatment 12 vs. Treatment 13) (Table 2). The average root weight cultivated in the treatment with 20 individual EW per pot was on the $27^{\text {th }}, 36^{\text {th }}$ and $42^{\text {nd }}$ days of the growing season, lower by $7.96 \%, 3.21 \%$ and $3.52 \%$ compared with the weight of roots in the variants with 10 individual EWs per pot. Nurhidayati et al. (2016) recorded both increase and decrease in cabbage yield with the increased number of EW of specie $P$. corethrurus in Vc. The composition of Vc and its origin decide what number of the EW will increase, and what number will decrease the crop yield.

In the first sampling in the treatment with 20 EWs, a significant decrease in the root weights was detected in two treatments in comparison to the radish root weights cultivated in the treatments with 10 numbers of EWs, in particular in the treatment with the $\mathrm{S}: \mathrm{Vc}$ ratio of 9:1 and in the treatment with the $\mathrm{S}: \mathrm{Vc}$ ratio of 4:1. In the second and third samplings, there was a considerable decrease in the root weights in the treatments with 20 numbers of $\mathrm{EW}$, only in the treatment with the least $(10 \%)$ content of $\mathrm{Vc}(\mathrm{S}: \mathrm{Vc}=9: 1)$ compared with the treatment with 10 EWs. This fact approves the hypothesis that red worm (E. fetida) probably attacks the root hairs in case of fodder insufficiency.

The number of EWs did not influence the thickness (diameter) of the roots (Table 4). The difference between the pairs of treatments $(6-7,8-9,10-11$, 12-13) was insignificant. Similarly, the differences in the leaf weights were insignificant, which indicates that the number of EWs did not affect the leaf weights in a considerable way. The average decreases in leaf weights in the treatments with 20 EWs were lowered on the $27^{\text {th }}$, $36^{\text {th }}$ and $42^{\text {nd }}$ days of the growing season by $4.50 \%$, $1.40 \%$ and $2.65 \%$ compared with the treatments with 10 EWs.

\section{Content of chlorophylls}

\section{Effect of time}

The total chlorophyll content (on average for all variants of the experiment) was lesser only by $2.43 \%$ $\left(8.17 \mathrm{mg} \cdot \mathrm{m}^{-2}\right)$ on the $42^{\text {nd }}$ day, comparing with that on the $36^{\text {th }}$ day of the growing season. Similarly, the ratio of chlorophylls $a$ content to chlorophylls $b$ content was lower on the $42^{\text {nd }}$ day, eventually similar to that on the $36^{\text {th }}$ day of the growing season, highlighting that chlorophyll $a$ always dominated over chlorophyll $b$. A slight decrease in the total chlorophyll contents in the radish plant leaves harvested 6 days later related to a shorter time interval between the particular samplings and also to the fact that the radish seeds did not germinate and emerge on the same day concurrently, but in the course of 3 days, so the age of the analysed leaves was lesser than the stated 6 days. It is evident that the recorded values are consistent with those of Ebbs and Uchil (2008), who stated that in the process of leaf ageing, the decrease in the total chlorophyll contents can be measured. The degradation of chlorophyll during ripening and plant ageing is a natural process (Kumar et al., 2019).

\section{Effect of $V c$}

The contents of chlorophylls $a$ and $b$ in radish leaves of both samplings increased progressively along with the increasing proportion of $\mathrm{Vc}$ in soil. Concurrently the chlorophyll $a$ to $b$ ratio was lowered, as a result of the fact that along with the increasing content of available $\mathrm{N}, \mathrm{Mg}, \mathrm{S}$ and other nutrients in soil, the content of the total chlorophyll in plants increases (Kováčik et al., 2014).

On average of variants $2-5$, the increase of chlorophyll $a, b, a+b$ contents was at the level of $38.78 \mathrm{mg} \cdot \mathrm{m}^{-2}, 27.05 \mathrm{mg} \cdot \mathrm{m}^{-2}$ and $65.83 \mathrm{mg} \cdot \mathrm{m}^{-2}$ on the $36^{\text {th }}$ day of vegetation period compared to the contents in the control variant (Treatment 1). On the $42^{\text {nd }}$ day of the growing season the increase achieved $41.9 \mathrm{mg} \cdot \mathrm{m}^{-2}$, $27.35 \mathrm{mg} \cdot \mathrm{m}^{-2}$ and $69.25 \mathrm{mg} \cdot \mathrm{m}^{-2}$. In the relative expression, on the $36^{\text {th }}$ day of the growing season the increases were $19.57 \%, 33.69 \%$ and $23.64 \%$, and on the $42^{\text {nd }}$ day of the growing season the increases were $22.15 \%, 35.02 \%$ and $25.91 \%$.

As the plant leaves contain more chlorophyll $a$ than chlorophyll $b$ (Novichkova et al., 2006, Noman et al., 2018), the absolute increase in total chlorophyll content as a result of the improved plant nutrition was higher in chlorophyll $a$ than in chlorophyll $b$; however, the relative increase was higher in chlorophyll $b$. Relatively higher increase of chlorophyll $b$ than chlorophyll $a$ content explains recorded decrease of chlorophyll $a: b$ 
ratio, along with the rising proportion of $\mathrm{Vc}$ in soil. The Vc increased relatively more chlorophyll $b$ than chlorophyll $a$ content. The highest ratio of chlorophyll $a: b$ was monitored in the control treatment.

On the $36^{\text {th }}$ day of the growing season, the differences in the chlorophyll contents between the particular treatments with (Treatments 2-5) and without $\mathrm{Vc}$ (Treatment 1) were significant. On the $42^{\text {nd }}$ day of the growing season, considerable differences occurred only in the treatments at $20 \%, 25 \%$ and $50 \%$ of the proportion of $\mathrm{Vc}$ in the soil. This finding is related to the decreasing positive impact of the added available nutrients on the formation of chlorophylls during running days of the growing season. The effect of the added nutrients depends on their doses, e.g. the lower the nutrient dose, the shorter is the effect.

\section{Effect of the presence of $E W$}

A comparison of the average values of chlorophyll contents in the treatments with (Treatments 6-13) and without EW (Treatments 2-5) indicate that the lower contents of chlorophyll $a$, chlorophyll $b$ and, consequently the total chlorophyll content, were obtained in the treatments with EW. At the same time the lower chlorophyll $a: b$ ratios were measured as a consequence of the fact that the decrease in chlorophyll $a$ content was higher than that of chlorophyll $b$. The decrease in chlorophyll $a$ on the $36^{\text {th }}$ and $42^{\text {nd }}$ days of the growing season was at the level of $2.40 \%$ and $2.84 \%$, and the decrease in chlorophyll $b$ achieved $0.79 \%$ and $0.29 \%$, respectively. The declines in chlorophylls $a$, $b a+b$ contents, caused by the presence of $\mathrm{EW}$ in the soil, were not statistically significant in any treatment. Therefore, it can be stated that EW tend to decrease the chlorophyll content in radish leaves, or that the effect of the EW on the chlorophyll content was insignificant.

\section{Effect of the number of EW}

The differences in the chlorophyll contents found between the pairs of treatments ( 6 and 7, 8 and 9, 10 and 11, 12 and 13) were minimal and statistically insignificant. On average, in the treatments with 20 EWs (Treatments 6, 8, 10, 12) the chlorophyll $a, b$, $a+b$ contents were lowered by $1.72 \%, 0.37 \%$ and $1.3 \%$ in comparison with the contents of chlorophylls in the treatments with 10 EWs (Treatments 7, 9, 11, 13). The lowest ratio of chlorophyll $a: b$ was registered in the treatment with 20 individual EWs (Table 5). The findings of the experiment show a higher number of EWs tending to decrease the content of chlorophyll in radish leaves to more than a lower number; however, the drops were insignificant.

\section{Vitamin C content}

\section{Effect of time}

On the $36^{\text {th }}$ day of the growing season the content of vitamin $\mathrm{C}$ in radish roots was lesser by $18.1 \mathrm{mg} \cdot \mathrm{kg}^{-1}$ compared with its content on the $42^{\text {nd }}$ day of the growing season. On the contrary, the opposite tendency was recorded in the leaves (Table 6). On the $36^{\text {th }}$ day of the growing season the content of vitamin $\mathrm{C}$ in the

Table 5. Impact of Vc and EW on chlorophyll $a$, chlorophyll $b$ and total chlorophyll content in radish leaves.

\begin{tabular}{|c|c|c|c|c|c|c|c|c|c|}
\hline \multicolumn{2}{|l|}{ Treatment } & \multicolumn{4}{|c|}{ 3. V. (36 days a.e) } & \multicolumn{4}{|c|}{ 9. V. (42 days a.e) } \\
\hline No. & Mark & chl. $a$ & chl. $b$ & chl. $a+b$ & chl. $a: b$ & chl. $a$ & chl. $b$ & chl. $a+b$ & chl. $a: b$ \\
\hline & & & $\mathrm{mg} \cdot \mathrm{m}^{-2}$ & & & & $\mathrm{mg} \cdot \mathrm{m}^{-2}$ & & \\
\hline 1 & $\mathrm{~S}$ & $198.2 \mathrm{a}$ & $80.3 \mathrm{a}$ & $278.5 \mathrm{a}$ & 2.47 & $189.2 \mathrm{a}$ & $78.1 \mathrm{a}$ & $267.3 \mathrm{a}$ & 2.42 \\
\hline 2 & $\mathrm{SV}_{9 \cdot 1}$ & $232.4 \mathrm{bc}$ & $99.3 \mathrm{bc}$ & $331.7 \mathrm{bcd}$ & 2.34 & $206.5 \mathrm{ab}$ & $89.8 \mathrm{~b}$ & $296.3 \mathrm{~b}$ & 2.30 \\
\hline 3 & $\mathrm{SV}_{4: 1}$ & $234.3 \mathrm{bc}$ & $104.7 \mathrm{bcd}$ & 339.0 cde & 2.24 & $235.4 \mathrm{c}$ & $105.6 \mathrm{c}$ & 341.0 cde & 2.23 \\
\hline 4 & $\mathrm{SV}_{3.1}^{4.1}$ & $238.6 \mathrm{c}$ & $109.9 \mathrm{bcd}$ & $348.5 \mathrm{de}$ & 2.17 & $240.1 \mathrm{c}$ & $111.1 \mathrm{c}$ & 351.2 cde & 2.16 \\
\hline 5 & $\mathrm{SV}_{1: 1}^{2.1}$ & $242.6 \mathrm{c}$ & $115.5 \mathrm{~d}$ & $358.1 \mathrm{e}$ & 2.10 & $242.4 \mathrm{c}$ & $115.3 \mathrm{c}$ & $357.7 \mathrm{~d}$ & 2.10 \\
\hline 6 & $\mathrm{SV}_{9.1}+\mathrm{EW}_{10}$ & $224.0 \mathrm{bc}$ & $97.8 \mathrm{~b}$ & $321.8 \mathrm{bc}$ & 2.29 & $199.8 \mathrm{a}$ & $89.3 \mathrm{~b}$ & $289.1 \mathrm{~b}$ & 2.24 \\
\hline 7 & $\mathrm{SV}_{9: 1}+\mathrm{EW}_{20}$ & $214.4 \mathrm{ab}$ & $97.4 \mathrm{~b}$ & $311.8 \mathrm{~b}$ & 2.20 & $194.7 \mathrm{a}$ & $88.4 \mathrm{ab}$ & $283.1 \mathrm{ab}$ & 2.20 \\
\hline 8 & $\mathrm{SV}_{4: 1}+\mathrm{EW}_{10}$ & $230.2 b c$ & $105.6 \mathrm{bcd}$ & $335.8 \mathrm{bcd}$ & 2.18 & $229.8 \mathrm{c}$ & $106.2 \mathrm{c}$ & $336.0 \mathrm{~cd}$ & 2.16 \\
\hline 9 & $\mathrm{SV}_{4: 1}+\mathrm{EW}_{20}$ & $227.8 \mathrm{bc}$ & $106.4 \mathrm{bcd}$ & $334.2 \mathrm{bcd}$ & 2.14 & $225.9 \mathrm{bc}$ & $106.5 \mathrm{c}$ & $333.4 \mathrm{c}$ & 2.12 \\
\hline 10 & $\mathrm{SV}_{3: 1}^{4: 1}+\mathrm{EW}_{10}^{20}$ & $238.6 \mathrm{c}$ & $109.9 \mathrm{bcd}$ & $348.5 \mathrm{de}$ & 2.17 & $237.9 \mathrm{c}$ & $111.2 \mathrm{c}$ & 349.1 cde & 2.14 \\
\hline 11 & $\mathrm{SV}_{3: 1}+\mathrm{EW}_{20}$ & $237.2 \mathrm{c}$ & $109.3 \mathrm{bcd}$ & 346.5 cde & 2.17 & $235.1 \mathrm{c}$ & $110.3 \mathrm{c}$ & 345.4 cde & 2.13 \\
\hline 12 & $\mathrm{SV}_{1.1}^{3: 1}+\mathrm{EW}_{10}$ & $240.4 \mathrm{c}$ & $113.5 \mathrm{~d}$ & $353.9 \mathrm{de}$ & 2.12 & $238.8 \mathrm{c}$ & $114.8 \mathrm{c}$ & $353.6 \mathrm{~cd}$ & 2.08 \\
\hline 13 & $\mathrm{SV}_{1: 1}+\mathrm{EW}_{20}$ & $237.7 \mathrm{c}$ & $112.1 \mathrm{~cd}$ & $349.8 \mathrm{de}$ & 2.12 & $234.3 \mathrm{c}$ & $114.4 \mathrm{c}$ & 348.7 cde & 2.05 \\
\hline $1-13$ & & 230.49 & 104.75 & 335.24 & 2.21 & 223.84 & 103.15 & 327.07 & 2.18 \\
\hline $2-5$ & & 236.98 & 107.35 & 344.33 & 2.21 & 231.10 & 105.45 & 336.55 & 2.20 \\
\hline $6-13$ & & 231.29 & 106.50 & 337.79 & 2.17 & 224.54 & 105.14 & 329.80 & 2.14 \\
\hline $6,8,10,12$ & & 233.30 & 106.70 & 340.00 & 2.19 & 226.58 & 105.38 & 331.95 & 2.155 \\
\hline $7,9,11,13$ & & 229.28 & 106.30 & 335.58 & 2.16 & 222.50 & 104.90 & 327.65 & 2.125 \\
\hline $\operatorname{LSD}_{0.05}$ & & 20.606 & 13.418 & 24.964 & - & 22.055 & 10.996 & 19.258 & - \\
\hline
\end{tabular}

3. V. - 3 May, 9. V. - 9 May, days a.e - days after emergence of plants, chl. $a$ - chlorophyll $a$, LSD ${ }_{0.05}-$ least significant difference at the level $\alpha=0.05$; different letter behind a numerical value respond to the statistically significant difference at the level $95.0 \%$.

EW, earthworms; Vc, vermicompost. 
leaves increased by $15.1 \mathrm{mg} \cdot \mathrm{kg}^{-1}$ in comparison to the content detected on the $42^{\text {nd }}$ day of the growing season. A higher content of vitamin $\mathrm{C}$ in older than younger leaves of lettuce and broccoli was shown by Omary et al. (2003) and Yamada et al. (2003). Similarly, Cheptoo et al. (2019) claim a higher content of vitamin $\mathrm{C}$ in older than younger leaves of amaranth plants. On the contrary, the decrease in the content of vitamin $\mathrm{C}$ in dill leaves in successive days of the growing season was measured by Lisiewska et al. (2006).

During both terms of radish harvesting the content of vitamin $\mathrm{C}$ in the leaves dominated over that in the roots in all treatments of the experiment. On average, in all the treatments the content of vitamin $\mathrm{C}$ was 2.50 times higher in the leaves than in the roots on the $36^{\text {th }}$ day of the growing season and 1.98 times higher on the $42^{\text {nd }}$ of the growing season.

\section{Effect of $V c$}

Along with increasing proportions of $\mathrm{Vc}$ in the growing media (Treatments 2-5), the content of vitamin C decreased in the radish phytomass aboveground and underground (Table 6). The reason was that the increasing proportion of $\mathrm{Vc}$ in the soil $(\mathrm{S}+\mathrm{Vc}=9: 1 ; 4: 1$, $3: 1,1: 1)$ also enhanced the content of inorganic nitrogen (the Vc contained 33.7 times more $\mathrm{N}_{\min }$ than the soil) (Table 1). The negative correlation was usually recorded between the inorganic nitrogen content in the soil and the vitamin C content in plants (Lisiewska and Kmiecik, 1996). The opposite effect of Vc on increase in the vitamin C content in cabbage leaves (Brassica oleracea) was presented by Nurhidayati et al. (2016).

The highest content of vitamin $\mathrm{C}$ in the roots and leaves was detected in the control treatment without Vc (Treatment 1). Conversely, the lowest content was recorded in the treatment with mixed $\mathrm{Vc}$ and $\mathrm{S}$ in the 1:1 ratio (Treatment 5), i.e. in the treatment where the highest quantity of Vc was used.

Along with the increasing content of $\mathrm{Vc}$ in the soil substrate, the roots-to-leaves vitamin $\mathrm{C}$ content ratio had increased (Table 6). It is evident that the decline in vitamin $\mathrm{C}$ content was more considerable in the leaves than in the roots as a result of higher applied doses of Vc. Similarly, the statistical significance of the decreases of vitamin $\mathrm{C}$ contents between Treatments $2-5$ was more distinctive in the evaluation of the vitamin $\mathrm{C}$ contents in leaves compared with roots. These data prove the fact that $\mathrm{Vc}$ decreased the vitamin $\mathrm{C}$ content more heavily in leaves than in roots, as a result of more intensive ageing of radish leaves than roots.

The radish roots from the last harvest (9 May) had a higher content of vitamin $\mathrm{C}$ than roots from the previous harvest ( 3 May). On the contrary, in the leaves the content of vitamin $\mathrm{C}$ declined between 3 and 9 May. The older leaves contained less vitamin $\mathrm{C}$ than the younger ones.

\section{Effect of EW}

Embedding of EW into the soil substrates containing Vc did not significantly affect the content of vitamin C

Table 6. Impact of $\mathrm{Vc}$ and $\mathrm{EW}$ on vitamin $\mathrm{C}$ content in radish roots and leaves.

\begin{tabular}{|c|c|c|c|c|c|c|c|}
\hline \multicolumn{2}{|c|}{ Treatment } & \multicolumn{2}{|c|}{ 3. V. (36 days a.e) } & \multicolumn{2}{|c|}{ 9. V. (42 days a.e) } & 3. V. & 9. V. \\
\hline & & Roots & Leaves & Roots & Leaves & \multicolumn{2}{|c|}{$\mathrm{R}: \mathrm{L}$} \\
\hline No. & Mark & \multicolumn{4}{|c|}{$\mathrm{mg} \cdot \mathrm{kg}^{-1}$} & & \\
\hline 1 & $\mathrm{~S}$ & $111.22 \mathrm{c}$ & $350.44 \mathrm{e}$ & $159.72 \mathrm{e}$ & $295.84 \mathrm{~g}$ & 0.317 & 0.540 \\
\hline 2 & $\mathrm{SVc}_{9: 1}$ & $100.14 b$ & $260.54 \mathrm{~d}$ & $118.68 \mathrm{~d}$ & 241.32 ef & 0.384 & 0.492 \\
\hline 3 & $\mathrm{SVc}_{4: 1}$ & $94.40 \mathrm{ab}$ & $237.95 \mathrm{c}$ & $110.00 \mathrm{bcd}$ & $222.74 \mathrm{~d}$ & 0.397 & 0.494 \\
\hline 4 & $\mathrm{SVc}_{3: 1}$ & $92.00 \mathrm{ab}$ & $215.23 \mathrm{ab}$ & $105.20 \mathrm{abc}$ & $206.50 \mathrm{bc}$ & 0.427 & 0.509 \\
\hline 5 & $\mathrm{SVc}_{1: 1}$ & $87.20 \mathrm{a}$ & $202.00 \mathrm{a}$ & $99.42 \mathrm{a}$ & $188.98 \mathrm{a}$ & 0.432 & 0.526 \\
\hline 6 & $\mathrm{SVc}_{9: 1}+\mathrm{EW}_{10}$ & $98.92 \mathrm{~b}$ & $257.06 \mathrm{~d}$ & $117.82 \mathrm{~d}$ & 240.88 ef & 0.385 & 0.489 \\
\hline 7 & $\mathrm{SVc}_{9: 1}+\mathrm{EW}_{20}$ & $99.82 \mathrm{~b}$ & $251.42 \mathrm{~cd}$ & $118.00 \mathrm{~d}$ & $242.36 \mathrm{f}$ & 0.397 & 0.487 \\
\hline 8 & $\mathrm{SVc}_{4: 1}+\mathrm{EW}_{10}$ & $94.88 \mathrm{ab}$ & $238.08 \mathrm{c}$ & $110.00 \mathrm{bcd}$ & $224.06 \mathrm{~d}$ & 0.399 & 0.491 \\
\hline 9 & $\mathrm{SVc}_{4: 1}+\mathrm{EW}_{20}$ & $95.62 \mathrm{ab}$ & $239.64 \mathrm{c}$ & $111.80 \mathrm{~cd}$ & $229.88 \mathrm{de}$ & 0.399 & 0.486 \\
\hline 10 & $\mathrm{SVc}_{3: 1}+\mathrm{EW}_{10}$ & $92.24 \mathrm{ab}$ & $216.34 \mathrm{ab}$ & $105.60 \mathrm{abc}$ & $209.50 \mathrm{c}$ & 0.426 & 0.504 \\
\hline 11 & $\mathrm{SVc}_{3: 1}+\mathrm{EW}_{20}$ & $93.60 \mathrm{ab}$ & $217.44 \mathrm{~b}$ & $106.80 \mathrm{abc}$ & $209.70 \mathrm{c}$ & 0.430 & 0.509 \\
\hline 12 & $\mathrm{SVc}_{1: 1}+\mathrm{EW}_{10}$ & $88.10 \mathrm{a}$ & $204.64 \mathrm{ab}$ & $101.00 \mathrm{ab}$ & $192.66 \mathrm{a}$ & 0.431 & 0.524 \\
\hline 13 & $\mathrm{SVc}_{1: 1}+\mathrm{EW}_{20}$ & $89.10 \mathrm{a}$ & $206.88 \mathrm{ab}$ & $101.80 \mathrm{ab}$ & $196.66 \mathrm{ab}$ & 0.431 & 0.518 \\
\hline $1-13$ & & 95.17 & 238.28 & 112.76 & 223.16 & 0.404 & 0.505 \\
\hline $2-5$ & & 93.44 & 228.93 & 108.33 & 214.89 & 0.410 & 0.505 \\
\hline $6-13$ & & 94.04 & 228.94 & 109.10 & 218.21 & 0.412 & 0.501 \\
\hline $6,8,10,12$ & & 93.54 & 229.03 & 108.61 & 216.78 & 0.410 & 0.502 \\
\hline $7,9,11,13$ & & 94.54 & 228.85 & 109.60 & 219.65 & 0.414 & 0.500 \\
\hline $\mathrm{LSD}_{0.05}$ & & 9.463 & 14.03 & 9.407 & 11.520 & - & - \\
\hline
\end{tabular}

No. - number, 24. IV. - 24 April, 3. V. - 3 May, 9. V. - 9 May, days a.e - days after emergence of plants, LSD $_{0.05}-$ least significant difference at the level $\alpha=0.05$; different letter behind a numerical value respond to the statistically significant difference at the level of $95.0 \%$.

EW, earthworms; Vc, vermicompost. 
in radish phytomass aboveground and underground (Treatment 2 vs Treatments 6 and 7, Treatment 3 vs Treatments 8 and 9, Treatment 4 vs Treatments 10 and 11, Treatment 5. vs Treatments 12 and 13) (Table 5). In both harvesting terms the vitamin $\mathrm{C}$ contents measured in the radish roots and leaves were the same in the variants $6-13$, or statistically insignificantly higher than the contents of vitamin $\mathrm{C}$ measured in the variants $2-5$. The average increases were 0.60 and $0.57 \mathrm{mg} \cdot \mathrm{kg}^{-1}$ (root) and $0.01 \mathrm{mg} \cdot \mathrm{kg}^{-1}$ and $3.52 \mathrm{mg} \cdot \mathrm{kg}^{-1}$ in the leaves. Xiang et al. (2016) published similar data; they also measured the statistically insignificant impact of EW of E. fetida specie on the vitamin $\mathrm{C}$ content in papaya fruits (Carica papaya L.).

The addition of EW to the treatment with $10 \%$ proportion of $\mathrm{Vc}$ of the total substrate weight tended to decrease the content of vitamin $\mathrm{C}$ in radish roots and leaves in comparison with the treatments containing more Vc $(20 \%, 25 \%$ and $50 \%)$. The drops were insignificant. The probable reason for this insignificant difference was the insufficient quantity of fodder for red worms in the substrate with $10 \%$ proportion of $\mathrm{Vc}$. The subsequent attack of root hairs by the EW induced a stress in radish plants. The positive effect of the EW ( $P$. corethrurus) up to 25 individuals per $\mathrm{m}^{2}$ on the vitamin $\mathrm{C}$ content in cabbage leaves was presented by Nurhidayati et al. (2016). On the contrary, along with the increasing number of EW in soil at above 25 individuals (50,75 and 100 individuals per $1 \mathrm{~m}^{2}$ ) the content of vitamin $\mathrm{C}$ in cabbage leaves decreased proportionally.

\section{Effect of the number of EW}

The number of EW did not significantly influence the vitamin $\mathrm{C}$ content in radish roots and leaves (Treatment 6 vs Treatment 7, Treatment 8 vs. Treatment 9, Treatment 10 vs. Treatment 11, Treatment 12 vs Treatment 13 Table 6). Nevertheless, it can be claimed that the content of vitamin C was slightly higher with 20 EWs added per pot than with $10 \mathrm{EWs}$ added per pot. The similar positive tendency of the impact of a higher number of EWs on the vitamin $\mathrm{C}$ content was measured also in the leaves.

\section{Nitrate content}

\section{Effect of time}

In the radish plants sampled during the first harvest (3 May), the nitrate content $\left(\mathrm{NaNO}_{3}\right)$ was higher than in plants sampled during the second harvest ( 9 May). The average decline of the nitrate contents in radish roots in the course of 6 days, i.e. between both harvest terms, was $197.57 \mathrm{mg} \cdot \mathrm{kg}^{-1}$ and $153.75 \mathrm{mg} \cdot \mathrm{kg}^{-1}$ in leaves, respectively - in all variants of the experiment (Table 7). The decrease in nitrate content in time (content of nitrates on 3 and 9 May) occurred in all the treatments. The decline in nitrate content with the following days of the growing season was also presented by $\mathrm{Li}$ et al. (2017). In their experiments the contents of nitrates in tobacco leaves measured from the $45^{\text {th }}$ to $75^{\text {th }}$ day after transplanting varied approximately from $100 \mathrm{mg} \cdot \mathrm{kg}^{-1}$ to $1,250 \mathrm{mg} \cdot \mathrm{kg}^{-1} \mathrm{NO}_{3}^{-}-\mathrm{N}$. On the contrary, Tabaglio et al. (2020) did not record the unambiguous dependence between the nitrate content in lettuce leaves and

Table 7. Impact of $\mathrm{Vc}$ and $\mathrm{EW}$ on the nitrates $\left(\mathrm{NaNO}_{3}\right)$ content in radish roots and leaves.

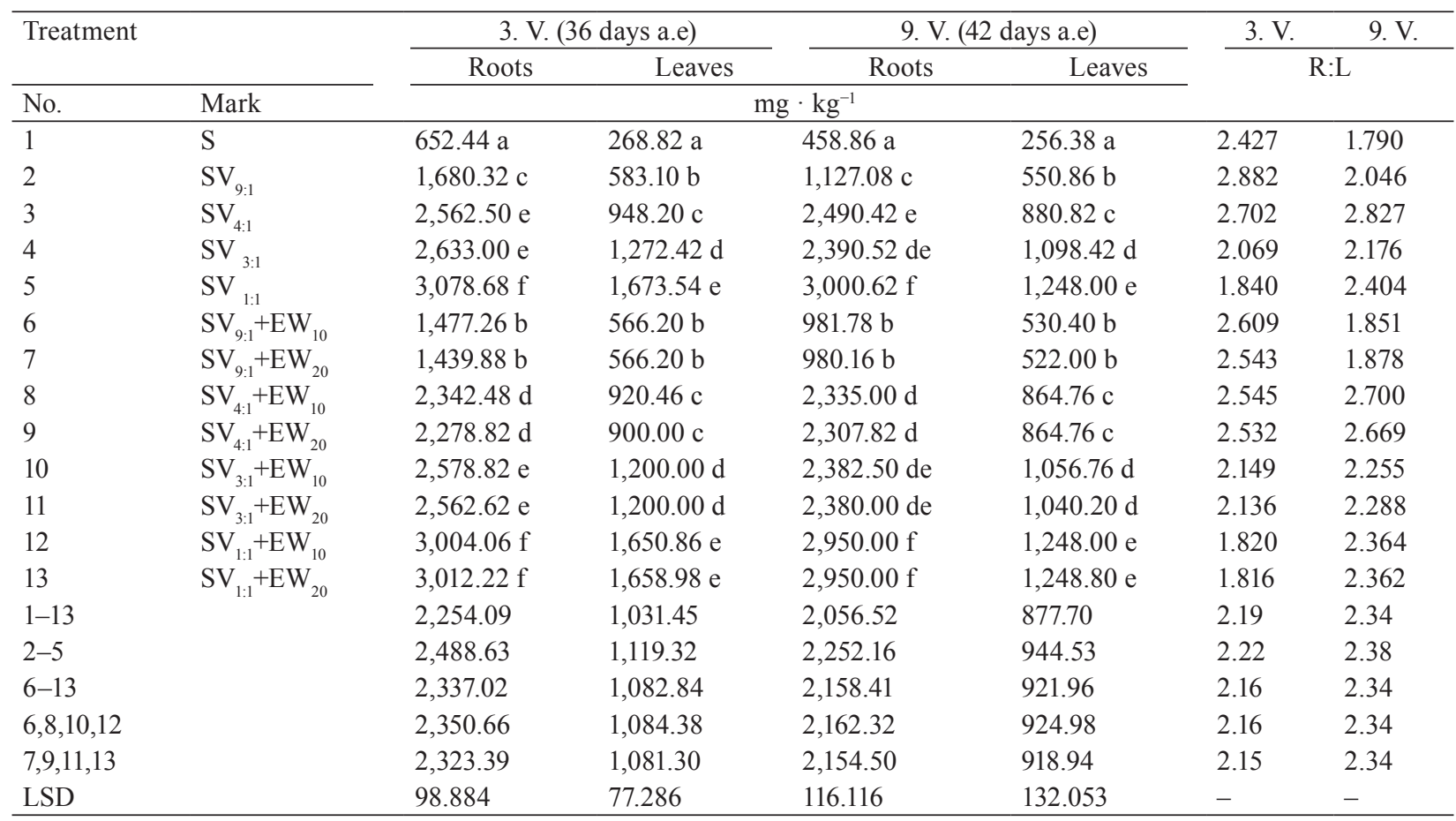

No. - number, 24. IV. - 24 April, 3. V. - 3 May, 9. V. - 9 May, days a.e - days after emergence of plants, LSD M.05 $_{-}$least significant difference at the level $\alpha=0.05$; different letter behind a numerical value respond to the statistically significant difference at the level $95.0 \%$.

EW, earthworms; Vc, vermicompost. 
duration of lettuce growing season in the last 6 days before lettuce harvest.

In the experiment, a higher decrease of nitrates content in roots compared to leaves was the result of higher nitrates content in the roots compared to the leaves. In the roots there was on average 2.26 times more nitrates than in the leaves in both the samplings. The opposite effect, i.e. higher content of nitrates in vegetable leaves than in roots is stated by Santamaria et al. (1999). Similarly, Zhen and Leigh (1990) detected a higher content of nitrates in wheat leaves than in roots. Conversely, the higher content of nitrates recorded in roots than in leaves corresponds with the data of Anjana and Iqbal (2007), who explained that vegetables forming reserve organs have a different mechanism for nitrates storage than leafy vegetables. A higher content of nitrates in roots than in leaves of different plant species was presented by Black et al. (2002). The site of accumulation of nitrates in plants is determined by the localisation of mechanisms reducing nitrates (leaf, root), which depends on a plant species (Hucklesby et al., 1990).

\section{Effect of $V_{C}$}

Along with the increasing quantity of $\mathrm{Vc}$ in the soil substrate, the content of nitrates was increasing in radish roots and leaves (Table 7). In Treatments 2-5 the content of $\mathrm{NaNO}_{3}$ in radish roots increased by $1,790.68 \mathrm{mg} \cdot \mathrm{kg}^{-1}$ and in leaves by $769.33 \mathrm{mg} \cdot \mathrm{kg}^{-1}$ on average in both sampling compared with the control variant 1 . The increase in content in the roots was 4.22 times and in leaves it was 3.93 times higher. The increase of nitrates content in radish phytomass along with the increase of quantity of $\mathrm{Vc}$ in the substrate was a consequence of the well-known dependence of the content of nitrates in a plant on the content $\mathrm{N}_{\text {in }}$ in soil, on the dose of inorganic nitrogen applied into soil in the form of the mineral or organic N fertilisers (Yuan et al., 2014; Adekiya et al., 2019). Low $N$ doses do not increase the nitrate contents in plants (Liao et al., 2009). The increase in nitrates content was accompanied by a decrease in the vitamin $\mathrm{C}$ contents (Tables 7 and 8). The increase in nitrate contents and the decrease in the vitamin $\mathrm{C}$ content along with the growth of application dose of $\mathrm{Vc}$ were presented by Papathanasiou et al. (2012).

\section{Effect of EW}

The comparison of nitrate contents in Treatments 2-5 with Treatments 6-13 (Table 7) indicates that the EW in the growing media showed a tendency to decrease the nitrate contents in radish roots and leaves. On average, in Treatments $2-5$ versus $6-13$, the drop in the content was insignificant in the leaves, at the levels of $3.26 \%$ and $2.39 \%$ between both the harvest periods (3 and 9 May). The decrease in the nitrate contents in the roots was significant in two treatments (with $10 \%$ and $20 \%$ content of $\mathrm{Vc}$ ) and was insignificant in two instances (treatment with $25 \%$ and $50 \%$ content of $\mathrm{Vc}$ ). On average, in Treatments $2-5$ vs $6-13$ the decline in nitrates contents in radish roots was $6.09 \%$ and $4.16 \%$ during the harvest period on 3 and 9 May, respectively. Based on the information that EW increases the nitrogen mobility in soils and the quantity of washed-up $\mathrm{N}-\mathrm{NO}_{3}$ from soil (Domínguez et al., 2004; Marhan et al., 2015), one may expect in the treatments with EW, an increased content of nitrates in radish plants. This assumption, however, was not true.

\section{Interdependences between the measured parameters}

Photosynthesis is a key process of maintaining life on the Earth, plant growth and the achievement of

Table 8. Relationship between the qualitative (nitrates and vitamin C contents) and quantitative yield parameters.

\begin{tabular}{|c|c|c|c|}
\hline \multirow[t]{2}{*}{ Parameter } & & \multicolumn{2}{|c|}{ Date of sampling } \\
\hline & & $\begin{array}{l}\text { 3. V. (36 days after emergence } \\
\text { of plants }\end{array}$ & $\begin{array}{l}\text { 9. V. (42 days after emergence } \\
\text { of plants }\end{array}$ \\
\hline Dependent & Independent & \multicolumn{2}{|c|}{ Correlation coefficient $(r)$} \\
\hline Weight of roots & Total chlorophyll & $0.514^{++}$ & $0.515^{++}$ \\
\hline Diameter of roots & & $0.488^{++}$ & $0.488^{++}$ \\
\hline Weight of leaves & & $0.600^{++}$ & $0.777^{++}$ \\
\hline \multirow{4}{*}{ Vitamin $\mathrm{C}$ in roots } & Total chlorophyll & $-0.621^{++}$ & $-0.740^{++}$ \\
\hline & Diameter of roots & $-0.340^{+}$ & $-0.585^{++}$ \\
\hline & Weight of roots & $-0.365^{++}$ & $-0.645^{++}$ \\
\hline & $\mathrm{NaNO}_{3}$ in roots & $-0.708^{++}$ & $-0.773^{++}$ \\
\hline \multirow{3}{*}{ Vitamin $\mathrm{C}$ in leaves } & Total chlorophyll & $-0.738^{++}$ & $-0.843^{++}$ \\
\hline & Weight of leaves & $-0.730^{++}$ & $-0.774^{++}$ \\
\hline & $\mathrm{NaNO}_{3}$ in leaves & $-0.836^{++}$ & $-0.900^{++}$ \\
\hline \multirow{3}{*}{$\mathrm{NaNO}_{3}$ in roots } & Total chlorophyll & $0.759^{++}$ & $0.911^{++}$ \\
\hline & Diameter of roots & $0.441^{++}$ & $0.436^{++}$ \\
\hline & Weight of roots & $0.500^{++}$ & $0.490^{++}$ \\
\hline \multirow{2}{*}{$\mathrm{NaNO}_{3}$ in leaves } & Total chlorophyll & $0.707^{++}$ & $0.880^{++}$ \\
\hline & Weight of leaves & $0.515^{++}$ & $0.729^{++}$ \\
\hline
\end{tabular}

No.-52, ${ }^{+}$statistically significant $(p<0.05),{ }^{++}$statistically highly significant $(p<0.01), \mathrm{n}$ - number of measurements. 
desired yields (Ashraf et al., 2016; Roca et al., 2016). Chlorophylls play a key role in it. The dependence between the weights of radish phytomass, as reached on the $36^{\text {th }}$ and $42^{\text {nd }}$ day of the growing season and the total chlorophylls contents (Tch) in leaves, as expressed by the correlation coefficient $r$, was highly evident. A higher dependence was recorded between the weight of leaves and the content of Tch than between the root weights and Tch content (Table 8). It is presumable that plants with higher contents of chlorophylls form higher phytomass of roots and leaves than those of plants with lower chlorophylls contents.

Vegetables represent an important component of human nutrition, while also having an impact on human health. Therefore, vegetable growers should apply such growing procedures which allow the achievement of high-quality yields. Vitamin $\mathrm{C}$ is a significant antioxidant substance that decreases the threat of arteriosclerosis, diseases of the circulatory system and some neoplasms (Korus, 2011). Together with other antioxidants, it is a suitable vegetable also for diabetics because of its antidiabetic effects (Banihani, 2017). The data in Table 8 indicate that a negative dependence exists between the weight of roots and the contents of vitamin $\mathrm{C}$, and a positive relationship between the weight of roots and the content of nitrates. Similar dependences were observed between the weight of leaves and the contents of vitamin $\mathrm{C}$ and the contents of nitrates in leaves. As the weight of plant roots and leaves and the content of chlorophylls depend considerably on the doses of $\mathrm{N}$ (Marschner, 2005), and also the chlorophylls content depends significantly on the $\mathrm{N}$ application rates and nitrogen content in the plant (Hallik et al., 2009; Gholizadeh et al., 2017), it is evident that the presented dependences (Table 8) affirm the impact of $\mathrm{N}$ nutrition on the vegetable quality, which is usually negative. Along with an increase of the $\mathrm{N}_{\text {in }}$ content in soil, the formation of phytomass and the quantity of nitrates is increased in it, akin to the quantity of vitamin $\mathrm{C}$ decreases (Chessin and Hicks, 1987; Lominadze and Nakashidze, 2016).

\section{CONCLUSIONS}

The impact of $\mathrm{Vc}$ on radish root and leaf weights increase was measurable on the $27^{\text {th }}$ day of the growing season. With increasing quantity of $\mathrm{Vc}$, the total chlorophylls content also increased proportionally. While the vitamin $\mathrm{C}$ content was decreasing, the nitrates content was rising in both the aboveground and underground phytomass. The weights of radish roots and leaves increased up to $20 \%$ of Vc content in the substrate. The Vc content above $20 \%$ led to a drop in root and leaves phytomass formation. The root and leaves yield was higher with $50 \% \mathrm{Vc}$ content in the substrate compared with the control treatment.

The EW had mostly a negative impact on the radish phytomass formation, particularly on the root weight and root diameter. The highest percentage of root weight drop cultivated in the treatments with EW was in the treatment where the growing medium contained the least quantity of $\mathrm{Vc}(10 \%)$, so it was the least quantity of fodder for the EW. On the contrary, the least percentage of root weight decrease, as resulted from the presented EW, was detected in the treatment where the substrate contained more Vc. The data allow to hypothesise that if red worms have sufficient fodder in their environment (compost, Vc, crop residues, etc.), they will not significantly attack the root hairs of young plants.

The impact of EW on the total chlorophylls, vitamin $\mathrm{C}$ and nitrate contents in the roots and leaves was nonsignificant. The number of $\mathrm{EW}$ did not influence the root diameter; the content of vitamin $\mathrm{C}$, however, affected the root weight. The dependence between the roots (leaves) weight and vitamin C contents in roots (leaves) was negative, while the dependence between the roots (leaves) weight and nitrates content in the roots (leaves) was positive.

The rapid positive effect of $\mathrm{Vc}$ on the phytomass of cultivated plants makes this organic fertiliser possible to be applied in the spring before sowing crops. Regarding the effectiveness of the use of $\mathrm{Vc}$, the proportion of $\mathrm{Vc}$ in the total substrate should not exceed $20 \%$. Also, in soil substrates with a significant number of EW, it is not appropriate to grow radish, that is, plants with a short growing season.

\section{FUNDING}

This article was supported by the National Scientific Granting Agency (VEGA) of the Ministry of Education of Slovak Republic via Research Project No. 1/0378/20.

\section{AUTHOR CONTRIBUTIONS}

P.K. contributed to the experiments and manuscript preparation. P.K. and K.O. designed the overall study. K.O. performed the chlorophyll content analyses and English correction of the manuscript. S.S. and I.L.-S. contributed to the statistical analyses of measured data and helped with the manuscript preparation.

\section{CONFLICT OF INTEREST}

The authors declare no conflict of interest.

\section{REFERENCES}

Adekiya, A. O., Agbede, T. M., Aboyeji, C. M., Dunsin, O., And Simeon, V. T. (2019). Effects of biochar and poultry manure on soil characteristics and the yield of radish. Scientia Horticulturae, 243, 457-463.

Akiyama, H., And Tsuruta, H. (2003). Effect of organic matter application on $\mathrm{N}_{2} \mathrm{O}, \mathrm{NO}$, and $\mathrm{NO}_{2}$ fluxes from an Andisol field. Global Biogeochemical Cycles, 17, 1100, doi: 10.1029/2002GB002016.

Anjana, S. U., And IQbal, M. (2007). Nitrate accumulation in plants, factors affecting the process, and human health implications. A review. Agronomy for Sustainable Development, 27, 45-57. 
Ashraf, R., Sultana, B., Iqbal, M., and Mushtaq, M. (2016). Variation in biochemical and antioxidant attributes of Raphanus sativus in response to foliar application of plant leaf extracts as plant growth regulator. Journal of Genetic Engineering and Biotechnology, 14, 1-8.

Banihani, S. A. (2017). Radish (Raphanus sativus) and diabetes. Nutrients, 9(9), 1014, doi: 10.3390/ nu9091014.

Berti, M., Fischer, S., Wilckens, R., And Hevia, F. (2009). Flax seed response to N, P, AND K fertilization in south central Chile. Chilean Journal of Agricultural Research, 69, 145-153.

BieleK, P., AND Kudejarov, V. N. (1991). Nitrogen cycle in the present agriculture. Bratislava, Slovakia: Príroda.

Bhatnagar, M. K., And Azhar, M. (2016). A study of chemical composition of some leafy vegetables of fatehpur district. International Journal of Science and Research, 5, 408-410.

Black, B. L., Fuchigami, L. H., and Coleman, G. D. (2002). Partitioning of nitrate assimilation among leaves, stems and roots of poplar. Tree Physiology, 22, 717-724.

Bremner, J. M. (1960). Determination of nitrogen in soil by the Kjeldahl method. Journal of Agricultural Science, 55, 11-33.

Brown, G. G., Barois, I., And Lavelle, P. (2000). Regulation of soil organic matter dynamics and microbial activity in the drilosphere and the role of interactions with other edaphic functional domains. European Journal of Soil Biology, 36, 177-198.

Brown, G. G., Edwards, C. A., and Brussaard, L. (2004). How earthworms effect plant growth: Burrowing into the mechanisms. In C. A. Edwards (Eds), Earthworm ecology (pp. 13-45). Boca Raton, USA: CRC Press.

Chakraborty, B., Kundu, M., and Chattopadhyay, R. N. (2016). Organic farming with bio-mulching A new paradigm for sustainable leaf yield \& quality of mulberry (Morus alba L.) under rainfed lateritic soil condition. Agriculture and Agricultural Science Procedia, 11, 31-37.

Chaudhuri, P. S., Paul, T. K., Dey, A., Datta, M., And Dey, S. K. (2016). Effects of rubber leaf litter vermicompost on earthworm population and yield of pineapple (Ananas comosus) in West Tripura, India. International Journal of Recycling of Organic Waste in Agriculture, 5, 93-103.

Cheptoo, G., Owino, W., And Kenji, G. (2019). Nutritional quality, bioactive compounds and antioxidant activity of selected African indigenous leafy vegetables as influenced by maturity and minimal processing. African Journal of Food Agriculture Nutrition and Development, 19, 14769-14789.

Chessin, D. A., And Hicks, J. R. (1987). The effect of nitrogen fertilizer, herbicides, and cultivar on nitrogen components of carrot roots. Scientia Horticulturae, 33, 67-73.

Cong, W.-F., Christensen, B. T., And Eriksen, J. (2019). Soil nutrient levels define herbage yield but not root biomass in a multispecies grass-legume ley. Agriculture, Ecosystems \& Environment, 276, 47-54.

Cooke, G. W. (1982). Fertilizing for maximum yield (pp. 465). Granada and London: ELBS.

Deng, M., Hou, M., Ohkama-Ohtsu, N., Yokoyama, T., Tanaka, H., Nakajima, K., Omata, R., and Bellingrath-Kimura，S. D. (2017). Nitrous oxide emission from organic fertilizer and controlled release fertilizer in tea fields. Agriculture, 7(3), 29, doi: 10.3390/agriculture7030029.

Doan, T. T., Ngo, P. T., Rumpel, C., and Nguyen, B. V. (2013). Interactions between compost, vermicompost and earthworms influence plant growth and yield: A one-year greenhouse experiment. Scientia Horticulturae, 160, 148-154.

Domínguez, J., Bohlen, P. J., And Parmelee, R. W. (2004). Earthworms increase nitrogen leaching to greater soil depths in row crop agroecosystems. Ecosystems, 7, 672-685.

Du, Y.-L., He, M.-M., Xu, M., Yan, Z., Zhou, Y.-Y., Guo, G.-L., Nie, J., Wang, L.-Q., Hou, H., AND LI, F.-S. (2014). Interactive effects between earthworms and maize plants on the accumulation and toxicity of soil cadmium. Soil Biology and Biochemistry, 72, 193-202.

Dziadowiec, H., And Gonet, S. S. (1999). A guide to the methods for determination of soil organic matter (p. 65). Warszawa, Poland: Prace Komisji Naukowej PTG.

EbBS, S., AND Uchil, S. (2008). Cadmium and zinc induced chlorosis in Indian mustard [Brassica juncea (L.) Czern] involves preferential loss of chlorophyll b. Photosynthetica, 46, 49-55.

Elmer, W. H. (2016). Effect of leaf mold mulch, biochar, and earthworms on mycorrhozal colonization and yield of asparagus affected by Fusarium crown and root rot. Plant Disease, 100, 2507-2512.

European Commission (EC). (1991). Directive of 12th December 1991 concerning the protection of waters against pollution caused by nitrates from agricultural ources (91/676/EEC). Official Journal of the European Communities, L375, 1-8.

European Commission (EC). (1999). Council Regulation (EC) No 1804/1999 of 19 July 1999 supplementing Regulation (EEC) No 2092/91 on organic production of agricultural products and indications referring thereto on agricultural products and foodstuffs to include livestock production. Official Journal the European Communities, L22, 1-28.

Garg, P., Gupta, A., And SAtya, S. (2006). Vermicomposting of different types of waste using Eisenia foetida: A comparative study. Bioresource Technology, 97, 391-395. 
Gholami, H., Fard, F. R., Saharkhiz, M. J., And Ghani, A. (2018a). Yield and physicochemical properties of inulin obtained from Iranian chicory roots under vermicompost and humic acid treatments. Industrial crops. Industrial Crops and Products, 123, 610-616.

Gholami, H., Saharkhiz, M. J., Fard, F. R., Ghani, A., AND NADAF, F. (2018b). Humic acid and vermicompost increased bioactive components, antioxidant activity and herb yield of chicory (Cichorium intybus L.). Biocatalysis and Agricultural Biotechnology, 14, 286-292.

Gholizadeh, A., Saberioon, M., BorŮvka, L., Wayayok, A., AND Soom, M. A. M. (2017). Leaf chlorophyll and nitrogen dynamics and their relationship to lowland rice yield for site-specific paddy management. Information Processing in Agriculture, 4, 259-268.

Van Groenigen, J. W., Lubbers, I. M., Vos, H. M. J., Brown, G. G., De Deyn, G. B., and Groenigen, K. J. (2014). Earthworms increase plant production: a meta-analysis. Scientific Reports, 4, 6365, doi: 10.1038/srep06365.

Hallik, L., Kulla, O, Ninnemets, Ü., and Aana, A. (2009). Contrasting correlation networks between leaf structure, nitrogen and chlorophyll in herbaceous and woody canopies. Basic and Applied Ecology, 10, 309-318.

HubÁČEK, J., AND BERNATZIK, K. (1976). Evaluation of some methods of nitrate nitrogen determination in plant material. Chemické listy, 70, 513-524 (in Czech).

Hucklesby, D. P., Emes, M. J., Bowsher, C. G., And Cammack, R. (1990). Nitrite reduction in the roots and leaves of Pisum Sativum. In W. R. Ullrich, C. Rigano, A. Fuggi, and P. J. Aparicio (Eds), Inorganic nitrogen in plants and microorganisms (pp. 210215). Berlin-Heidelberg, Germany: Springer-Verlag.

KmeŤová, M., Kováčik, P., And Renčo, M. (2013). The effect of different doses application of dry granulated vermicompost on yield parameters of maize and potatoes. Acta Fytotechnica et Zootechnica, 1, 8-14.

Kong, X. B., Lal, R., Li, B. G., Liu, H. B., Li, K. J., Feng, G. L., Zhang, Q. P., AND Zhang, B. B. (2014). Fertilizer intensification and its impacts in China's HHH plains. Advances in Agronomy, 125, 135-169.

Korus, A. (2011). Level of vitamin C, polyphenols, and antioxidant and enzymatic activity in three varieties of kale (Brassica oleracea L. var. acephala) at different stages of maturity. International Journal of Food Properties, 14, 1069-1080.

KováčIK, P. (1997). Analysis of soils, plants, fertilizers and calculation of nutrient doses to field and garden crops (p. 104). Nitra, Slovakia: SUA in Nitra (in Slovak).

Kováčik, P., Havrlentová, M., And ŠimanskÝ, V. (2014). Growth and yield stimulation of winter oilseed rape (Brassica napus L.) by Mg-Titanit fertiliser. Agriculture (Pol'nohospodárstvo), 60, 132-141.
KovÁčiK, P., ŠAlamún, P., AND WierzbowsKa, J. (2018a). Vermikompost and Eisenia foetida as factors influencing the formation of radish phytomass. Agriculture (Pol'nohospodárstvo), 64, 49-56.

Kováčik, P., Šalamún, P., Smoleń, S., ŠKarpa, P., ŠImANSKÝ, V., AND MORAVČ́́K, L. (2018b). Determination of the carrot (Daucus carota L.) yields parameters by vermicompost and earthworms (Eisenia foetida). Slovak Journal of Food Sciences, 12, 520-526.

Kumar, S., Kumar, R., Pal, A., And Chopra, D. S. (2019). Enzymes. In E. M. Yahia and A. Carrillo-López (Eds), Postharvest physiology and biochemistry of fruits and vegetable (pp. 335-358). Duxford, UK: Woodhead Publishing Limited.

Lichtenthaler, H. K. (1987). Chllorophylls and carotenoides: Pigments of photosynthetic biomembranes. Methods in Enzymology, 148, 350-382.

Li, H., Cong, R., Ren, T., Li, X., Ma, C., Zheng, L., Zhang, Z., AND Lu, J. (2015). Yield response to N fertilizer and optimum $\mathrm{N}$ rate of winter oilseed rape under different soil indigenous $\mathrm{N}$ supplies. Field Crops Research, 181, 52-59.

Li, Y., Shi, H., Yang, H., Zhou, J., Wang, J., Bai, R., AND Xu, D. (2017). Difference between burley tobacco and flue-cured tobacco in nitrate accumulation and chemical regulation of nitrate and TSNA contents. Journal of Chemistry, 2017, 4357456, doi: 10.1155/2017/4357456.

LiaO, Y., Rong, X., Zheng, S., LiU, Q., Fan, M., Peng, J., AND XIE, G. (2009): Influences of nitrogen fertilizer application rates on radish yield, nutrition quality, and nitrogen recovery efficiency. Frontiers of Agriculture in China, 3, 122-129.

Lisiewska, Z., AND KMIECIK, W. (1996). Effects of level of nitrogen fertilizer, processing conditions and period of storage of frozen broccoli and cauliflower on vitamin C retention. Food Chemistry, 57, 267-270.

LisiewskA, Z., KMiecik, W., And Korus, A. (2006). Content of vitamin C, carotenoids, chlorophylls and polyphenols in green parts of dill (Anethum graveolens L.) depending on plant height. Journal of Food Composition and Analysis, 19, 134-140.

León, A. P., Martín, J. P., And Chiesa, A. (2012). Vermicompost application and growth patterns of lettuce (Lactuca sativa L.). Agricultura Tropica et Subtropica, 45, 134-139.

Lominadze, S., AND NAKASHidze, N. (2016). The influence of nitrogen fertilizers on nitrate accumulation in leaves of orange Washington Navel. Annals of Agrarian Science, 14, 233-236.

Manojlović, M., ČAabilovski, R., Nikolić, L., Džigurski, D., ŠeremeŠić, S., And Bavec, M. (2017). Ground cover management and farmyard manure effects on soil nitrogen dynamics, productivity and economics of organically grown lettuce (Lactuca sativa L. 
subsp. secalina). Journal of Integrative Agriculture, 16, 947-958.

Marhan, S., Aubert, J., And Poll, Ch. (2015). Additive effects of earthworms, nitrogen-rich litter and elevated soil temperature on $\mathrm{N}_{2} \mathrm{O}$ emission and nitrate leaching from an arable soil. Applied Soil Ecology, 86, 55-61.

Marschner, H. (2005). Mineral nutrition of higher plants (p. 889). San Diego, CA/London: Elsevier Academic Press.

Menlich, A. (1984). Mehlich 3 soil test extractant: A modification of Mehlich 2 extractant. Communication in Soil Science and Plant Analysis, 15, 1409-1416.

Najuari, F., and Ghasemi, S. (2018). Changes in chemical properties of sawdust and blood powder mixture during vermicomposting and the effects on the growth and chemical composition of cucumber. Scientia Horticulturae, 232, 250-255.

Nurhidayati, N., Ali, U., And Murwani, I. (2016). Yield and quality of cabbage (Brassica oleracea L. var. capitata) under organic growing media using vermicompost and earthworm Pontoscolex corethrurus inoculation. Agriculture and Agricultural Science Procedia, 11, 5-13.

Noman, A., Ali, Q., Maqsood, J., Iqbal, N., Javed, M. T., Rasool, N., and Naseem, J. (2018). Deciphering physio-biochemical, yield, and nutritional quality attributes of water-stressed radish (Raphanus sativus L.) plants grown from Zn-Lys primed seeds. Chemosphere, 195, 175-189.

Novichkova, N. S., Romanova, A. K., Ignat'ev, A. R., Vlasova, T. A., Kreslavskit, V. D., and Ivanov, B. N. (2006). Carbonic anhydrase in leaves during radish plant ontogeny and glucose effect. Russian Journal of Plant Physiology, 53, 439-448.

NweKe, I. A. (2017). Effect of compost and earthworm production on soil properties, growth and dry matter yield of maize in crude oil degraded soil. Journal of Soil Science and Environmental Management, 8, 1-10.

Omary, M. B., Brovelli, E. A., Pusateri, D. J., David, P., Rushing, J. W., And Fonseca, J. M. (2003). Sulforaphane potential and vitamin $\mathrm{C}$ concentration in developing heads and leaves of broccoli (Brassica oleracea var. italica). Journal of Food Quality, 26, 523-530.

Osone, Y., And TAteno, M. (2003) Effects of stem fraction on the optimization of biomass allocation and maximum photosynthetic capacity. Functional Ecology, 17, 627-636.

Papathanasiou, F., Papadopoulos, I., Tsakiris, I. And Tamoutsidis, E. (2012). Vermicompost as a soil supplement to improve growth, yield and quality of lettuce (Lactuca sativa L.). Journal of Food, Agriculture \& Environment, 10, 677-682.

Poorter, H., Niklas, K. J., Reich, P. B., Oleksyn, J., Poot, P., AND Mommer, L. (2012). Biomass allocation to leaves, stems and roots: Meta-analyses of interspecific variation and environmental control. New Phytologist, 193, 30-50.

Roca, M., Chen, K., and Pérez-Gálvez, A. (2016). Chlorophylls. In R. Carle and R. Schweiggert (Eds), Handbook on natural pigments in food and beverages: Industrial applications for improving food color (pp. 125-158). Cambridge, UK, Elsevier: Woodhead.

Ruiz, E., Alonso-Azcárate, J., And Rodríguez, L. (2011). Lumbricus terrestris L. activity increases the availability of metals and their accumulation in maize and barely. Environmental Pollution, 159, $722-728$.

Russell, L., Farrish, K., Damoff, G., Coble, D., And Young, L. (2016). Establishment of earthworms on reclaimed lignite mine soils in east Texas. Applied Soil Ecology, 104, 125-130.

Santamaria, P., Elia, A., Serio, F., and Todaro, E. (1999). A survey of nitrate and oxalate conteent in retail fresh vegetables. Journal of the Science of Food and Agriculture, 79, 1882-1888.

Schulten, H. R., And Schnitzer, M. (1998). The chemistry of soil organic nitrogen (review). Biology and Fertility of Soils, 26, 1-15.

Sharma, S., Pradhan, K., Satya, S., and Vasudevan, P. (2005). Potentiality of earthworms for waste management and in other uses - A review. The Journal of American Science, 1, 1-16.

Sizmur, T., Palumbo-Roe, B., Watts, M. J., And Hodson, M. E. (2011). Impact of the earthworm Lumbricus terrestris (L.) on $\mathrm{As}, \mathrm{Cu}, \mathrm{Pb}$ and $\mathrm{Zn}$ mobility and speciation in contaminated soils. Environmental Pollution, 159, 742-748.

Stan, M., Soran, M. L., and Marutoiu, C. (2014). Extraction and HPLC determination of the ascorbic acid content of three indigenous spice plants. Journal of Analytical Chemistry, 69, 998-1002.

Suqiura, D., and Tateno, M. (2011). Optimal leaf-toroot ratio and leaf nitrogen content determined by light and nitrogen availabilities. PloS ONE, 6, e22236, doi: 10.1371/journal.pone.0022236.

ŠESTÁK, Z., AND ČATSKÝ, J. (1966). Methods of studying photosynthetic plant production (p. 396). Praha, Czechoslovakia: Academia Praha.

Tabaglio, V., Boselli, R., Fiorini, A., Ganimede, C., Beccari, P., Santelli, S., and Nervo, G. (2020). Reducing nitrate accumulation and fertilizer use in lettuce with modified intermittent nutrient film technique (NFT) system. Agronomy, 10, 1208, doi: 10.3390/agronomy10081208.

Tripathi, G., and Bhardwaj, P. (2004). Comparative studies on biomass production life cycles and composting efficiency of Eisenia foetida (Savigny) and Lampito mauritii (Kinberg). Bioresource Technology, 92, 275-283.

VAněK, V., Ložek, O., Balík, J., PavlíkovÁ, D., And TLustoš, P. (2013). Výživa polných a záhradných plodin (p. 175). Nitra, Slovakia: Profi Press SK s.r.o. 
Wright, S. F. And Upadhyay, A. A. (1998). A survey of soils for aggregate stability and glomaiin glycoprotein produced by hyphae of arbuscular mycorrhizal fungi. Plant and Soil, 198, 97-107.

Wu, D., Feng, Y., Xue, L., Liu, M., Yang, B., Hu, F., AND YANG, L. (2019). Biochar combined with vermicompost increases crop production while reducing ammonia and nitrous oxide emissions from a paddy soil. Pedosphere, 29, 82-94.

Xiang, H., Zhang, J., Guo, L., and Zhao, B. (2016). In situ earthworm breeding in orchards significantly improves the growth, quality and yield of papaya (Carica papaya L.). PeerJ, 4, e2752, doi: 10.7717/ peerj.2752.

Xiao, Z., Wang, X., Koricheva, J., Kergunteuil, A., Le Bayon, R.-C., Liu, M., Hu, F., and Rasmann, S. (2018). Earthworms affect plant growth and resistance against herbivores: A meta-analysis. Functional Ecology, 32, 150-160.

Yamada, C., Iwasaki, Y., and Yoshida, K. (2003). Effect of growth stage on contents of reducing sugar, ascorbic acid, oxalate and nitrate in spinach. Journal of the Japanese Society for Nutrition and Food Science, 56, 167-173.

Yuan, W.-L., Yuan, S.-Y., WanG, Q.-F., Gan, C.-X., LiU, Y.-H., AND MeI, S.-Y. (2014). Effect of different amount of $\mathrm{N}$-fertilizers on growth, root yield and nitrate content of white radishes in Southern China. Journal of Food, Agriculture \& Environment, 12, 302-304.

Zayed, M. S., Hassanein, M. K. K., Esa, N. H., and Abdallah, M. M. F. (2013). Productivity of pepper crop (Capsicum annuum L.) as affected by organic fertilizer, soil solarization, and endomycorrhizae. Annals of Agricultural Science, $58,131-137$.

Zhen, R. G., And Leigh, R. A. (1990). Nitrate accumulation by wheat (Triticum aestivum) in relation to growth and tissue $\mathrm{N}$ concentrations. Plant and Soil, 124, 157-160.

Received: June 1, 2021; accepted: April 9, 2021 